IZA DP No. 7919

Immigration:

What about the Children and Grandchildren?

Arthur Sweetman

Jan C. van Ours

January 2014 


\title{
Immigration: What about the Children and Grandchildren?
}

\author{
Arthur Sweetman \\ McMaster University \\ and IZA \\ Jan C. van Ours \\ CentER, Tilburg University, \\ University of Melbourne, CEPR, CESifo and IZA
}

\author{
Discussion Paper No. 7919 \\ January 2014
}

\author{
IZA \\ P.O. Box 7240 \\ 53072 Bonn \\ Germany \\ Phone: +49-228-3894-0 \\ Fax: +49-228-3894-180 \\ E-mail: iza@iza.org
}

Any opinions expressed here are those of the author(s) and not those of IZA. Research published in this series may include views on policy, but the institute itself takes no institutional policy positions. The IZA research network is committed to the IZA Guiding Principles of Research Integrity.

The Institute for the Study of Labor (IZA) in Bonn is a local and virtual international research center and a place of communication between science, politics and business. IZA is an independent nonprofit organization supported by Deutsche Post Foundation. The center is associated with the University of Bonn and offers a stimulating research environment through its international network, workshops and conferences, data service, project support, research visits and doctoral program. IZA engages in (i) original and internationally competitive research in all fields of labor economics, (ii) development of policy concepts, and (iii) dissemination of research results and concepts to the interested public.

IZA Discussion Papers often represent preliminary work and are circulated to encourage discussion. Citation of such a paper should account for its provisional character. A revised version may be available directly from the author. 


\section{ABSTRACT}

\section{Immigration: What about the Children and Grandchildren?*}

Intergenerational immigrant integration is central to the economic growth and social development of many countries whose populations comprise a substantial share of the children and grandchildren of immigrants. In addition to basic demographics, relevant economic theories and institutional features are surveyed to assist in understanding these phenomena. Building on this foundation, educational and labor market success across the immigrant generations are reviewed, and then studies on the evolution of social outcomes across those same generations are discussed. Overall, substantial cross-national heterogeneity in outcomes is observed as various sources of immigration interact with distinct national labor markets and educational/social contexts that have diverse approaches to integrating immigrants.

JEL Classification: J15

Keywords: second-generation immigration, 1.5-generation immigration, educational attainment, labor market position, intergenerational assimilation, economic integration

Corresponding author:

Jan C. van Ours

Tilburg University

P.O. Box 90153

5000 LE Tilburg

The Netherlands

E-mail: vanours@uvt.nl

\footnotetext{
* This paper is forthcoming in: Chiswick, B.R. and P.W. Miller (Eds.), Handbook of the Economics of International Migration, Vol. 1, Amsterdam: Elsevier.

The authors thank an anonymous referee for helpful comments. The opinions expressed herein need not reflect those of the government of Ontario.
} 


\section{Introduction}

Immigrants' children and grandchildren comprise a substantial and growing proportion of the populations of developed countries, and the success of the second and subsequent immigrant generations has sizeable implications for the development of those nations. These individuals' social, cultural and economic outcomes reflect the long-term process by which immigrants are integrated into host societies and - even if only recognized in retrospect - are crucial elements of nation building. Economists are interested in empirically documenting the patterns of intergenerational outcomes within countries and in comparing such outcomes across nations; in doing so they have observed interesting, and sometimes surprising, patterns. However, even more importantly, they aim to develop an understanding of the mechanisms by which these outcomes come about, together with an appreciation of the interactions between government policies, the behavior of firms, and the preferences and actions of individuals, families and communities. Attempts to estimate causal impacts are made when credible sources of exogenous variation exist, but much of the literature is descriptive using economic theory to interpret the observed empirical relationships.

While the migration of persons has been a global phenomenon since before the dawn of civilization, we focus on the past several decades and the intergenerational integration of migrants in developed countries, especially those of Europe and the "New World" with a focus on the traditional major immigrant receiving nations - i.e., the United States, Australia, Canada and New Zealand. ${ }^{1}$ Among these nations there have been massive changes in this time frame. Until a few decades ago Europe primarily experienced outmigration. According to historians, about 60 million Europeans moved away from the Old Continent in the period 1820-1940. Two-thirds of them went to the United States, with most of the rest going to the remainder of the New World. While that flow continues with, for example, 10.5 million persons migrating to the United States from Europe in the first decade of the twenty-first century, concurrently Europe is now attracting more migrants in proportion to its population than the United States, with most arriving from less developed nations (Boeri and van Ours, 2013). Moreover, change is also happening for the traditional major immigrant receiving nations. Since the 1960s their range of source countries has expanded while immigration rates have continued apace or increased. Although the United States and the other traditional receiving countries have more experience with the intergenerational integration of new immigrants, both sets of countries are facing new challenges as young immigrants and the children of immigrants -- frequently from less developed backgrounds and comprising diverse linguistic groups -- enter into education systems, integrate into labor markets, and establish social connections with the existing populations.

Research and policy regarding intergenerational immigrant integration have come to the fore as a result of evolving migration patterns. Although increasingly important in both Europe and the traditional immigrant receiving countries, many specific issues related to the economic integration of second-generation migrants take quite different forms in each country grouping, and in each individual country. Broadly speaking, the children of immigrants in Europe tend to be younger than those in the traditional immigrant receiving countries, and the European nations also have fewer institutions associated with intergenerational integration. Moreover, for geographic, post-colonial and other reasons, source countries tend to be concentrated within host countries but to differ across them. Marked differences can also be observed in average levels of education, the

${ }^{1}$ We do not focus on South and Central America since there is little extant economic research and these countries have experienced relatively little immigration in the past century. 
percentage of the children of immigrants who speak the receiving country language(s) at home, and other similar characteristics that in part reflect historic and current receiving country policy choices regarding both immigrant selection and settlement. Jointly, this enormous diversity in immigrant characteristics, and national policies and contexts, implies substantial heterogeneity in intergenerational outcomes both across and within nations. However, given how little is known about the interactions among these drivers of outcomes, generalizations are difficult with much research yet required to understand the implications of the alternative approaches of different countries.

The set-up of this chapter is as follows. Section 2 discusses conceptual and measurement issues related to immigrants being referred to as second-generation. Usually, second-generation immigrants are defined as native born offspring of at least one immigrant parent but definitions vary and measurement is not always straightforward. In section 3 we provide basic demographic information about second-generation immigrants. The population in some countries consists of a high share of second-generation immigrants while in other countries this population is relatively small. There is a lot of heterogeneity when it comes to country of origin of the parents of secondgeneration immigrants and there are many linguistic and cultural differences between immigrants and native populations which sometimes hamper integration. In section 4 we discuss economic theory related to intergenerational economic integration of immigrants into receiving developed countries. In this section we also discuss institutions affecting intergenerational integration. Section 5 presents information about the educational attainment and educational performance of secondgeneration immigrants. Whereas in traditional immigrant receiving countries second-generation immigrants often outperform natives in terms of educational attainment, in Europe secondgeneration immigrants perform worse than natives. Section 6 is on labor market outcomes for second-generation immigrants. Section 7 describes the evolution of a number of cultural and social outcomes across immigrant generations. Section 8 concludes and provides thoughts on future research.

\section{Initial Conceptual and Measurement Issues}

Although most immigration research focuses on adult migrants, long term outcomes are observed in the experiences of child immigrants, and the children and grandchildren of immigrants. In this context, immigration can be thought of as having various "generations". Although terminology varies, most economists define first-generation immigrants to be those persons who permanently, or at least for an extended period, migrate from one country to another. Secondgeneration immigrants are then the native (i.e., receiving or host country) born offspring of immigrant parent(s). ${ }^{2}$ However, in some research contexts the first-generation might not be an individual but, for example, the first cohort of immigrants arriving in a particular destination from a "new" source country or ethnic group, or as part of a new wave of immigration as in Borjas (1994). This phraseology is both intuitive and a useful rhetorical approach, but economists need to be careful to understand exactly what definition is being used in any particular study since there is wide variation in the details.

For some research questions this simple categorization is insufficient since, for example, first-generation immigrants who arrive at a young age are often more similar to second-generation ones than to adults from the first-generation. Individuals who immigrate to a new country before or during their early teens bring with them characteristics from their home country but experience

\footnotetext{
${ }^{2}$ Outside of economics, first-generation sometimes indicates those born to migrants in the receiving country post-immigration.
} 
at least some of their formative years while in a new country. They are thus halfway between the first- and second-generations. For these individuals the term 1.5 generation - sometimes attributed to Rumbaut (2004) who examines generational issues from a sociological perspective - is frequently used.

Some authors, such as Ramakrishnan (2004), refer to the native born with one native- and one foreign-born parent as the 2.5 generation. Compared to the 2.0 generation with two foreignborn parents, this generation can be therefore thought of as halfway between second and third. However, in accord with most of the economics literature we refer to both groups as the secondgeneration while distinguishing between those with two foreign-born parents, as opposed to a single such parent. As will be seen, it turns out that distinguishing between the varieties of the second generation has empirical ramifications, although the ranking of outcomes across those with one versus two immigrant parents varies across countries with different policy regimes. Continuing with the generational logic, third-generation immigrants are native born children of two native born parents where at least one grandparent is foreign-born. However, the phrase third-generation is also sometimes more loosely employed to encompass the broader situation where the individual and both parents are native born regardless of the individual's grandparents' birthplace. That is, the third and higher order generations are sometimes merged, but this broader grouping is also referred to by some writers as the $3+$ generation to distinguish it from the "true" third-generation. ${ }^{3}$

Beyond the notion of immigrant generations, of relevance to the interpretation of much empirical work are differences in the details of the definitions employed across data sources. International comparisons are particularly sensitive to these issues since superficially similar terminology sometimes defines somewhat different populations. One relevant example is that data collection agencies vary in the degree to which they distinguish between permanent, temporary, undocumented, and other migration groups. For Eurostat (2011, p143), immigration, including 1.5 and second generation immigration, "means an action by which a person establishes his or her usual residence in the territory of a country for a period that is, or is expected to be, at least 12 months, having previously been usually resident in another country." In contrast, Canada and Australia carefully distinguish between those legally defined as temporary versus permanent residents (with permanent migrants frequently termed immigrants, or sometimes in Australia settlers, and research on "immigration" commonly excluding temporary migrants). In Canada many recent censuses have explicit questions identifying temporary residents and many researchers remove these individuals from the sample for analysis. For the United States, much attention is paid to the counting of undocumented (sometimes termed illegal) immigrants, and commonly used data sets such as the Current Population Survey (CPS) are thought to capture most such individuals (Cohn and Passel, 2011). Of course, some ex ante permanent residents become ex post temporary ones, but the definition employed establishes the (sub-) population being studied.

At a minimum, Eurostat and American data sources such as the CPS, since they use more encompassing definitions, will appear to indicate larger counts than would, for example, Australian of Canadian census definitions applied to the same population. In the same way, including or excluding the children of undocumented immigrants in the United States has appreciable implications for studying the second generation. A similar measurement issue arises in categorization using country of birth versus citizenship at birth, which can differ for a modest but

\footnotetext{
${ }^{3}$ Although little economic research addresses these nuances, potentially empirically important variations are feasible based on this generational theme. Children with step-parents may experience multiple distinct influences, as might, for example, those born to parents temporarily residing outside of their native country, or whose parents have multiple citizenships and/or national allegiances.
} 
non-ignorable share of the population.

Links between the first and second generation can also be approached quite differently across studies. While some data sources have explicit information about each respondent's parents' migration status and/or characteristics (especially education), in many cases immigrant generations cannot be directly identified in the available data, and assumptions based on age, and ethnicity or source country, are used to (loosely) categorize individuals. Even when detailed information exists, complexity and/or sample size restrictions may motivate aggregating various groups, and this can be approached quite differently across studies.

When studies explicitly focus on the intergenerational transmission of economic outcomes within ethnic groups, measurement and interpretational issues arise from the grouping or clustering of individuals based on ancestry or ethnicity survey questions. ${ }^{4}$ There are several aspects to this. First, second or subsequent generation immigrants may have multiple ethnic ancestries, with this phenomenon becoming increasingly important for higher order generations. But, many surveys permit only a single response and even when multiple responses are permitted researchers, because of sample size and complexity issues, frequently focus on a single one. No adequate response to this issue appears to exist in the literature at the moment.

Second, post-migration integration might cause individuals to identify less strongly with their ancestral ethnic identity. If a particular ethnicity gains in stature, then individuals previously on the margin of that ethnic group may commence to identify with it. This measurement issue might bias coefficient estimates in ways that make answering relevant economic research questions difficult. For example, if individuals within a particular ethnic group who earn above average wages are, across generations, less likely to identify with that group, then the measured rate of intergenerational economic integration (also called intergenerational economic assimilation) will be biased down. Duncan and Trejo (2012) detail the importance of ethnic attrition in the United States arguing that the biases are substantial and vary in direction across ethnic groups. They also note that the changes in the wording of the Current Population Survey (CPS) in 2003 reduced, but did not eliminate, ethnic attrition. Their work clearly points to the importance of survey design on this front. Of course, this is a measurement issue that arises in contexts other than immigration, and is particularly common in studying discrimination and interethnic labor market outcomes gaps, for example the Aboriginal labor market outcomes studied by Kuhn and Sweetman (2002).

More broadly, consider how individuals of British or Indian ancestry, but whose immediate forebears resided in Kenya for two or three generations, would be categorized across survey instruments. Depending on whether the question posed is about "country of origin", "ethnic ancestry", or a concept such as "visible minority status", the classification could be quite different. Canada's 2006 census has independent questions regarding these three concepts, which allows the prevalence of such issues to be explored. Statistics Canada (2008) reports, for example, that of those who reported Black visible minority status, $11.6 \%$ reported their ethnic ancestry as British Isles, $10.9 \%$ reported it as Canadian, and $4.1 \%$ reported French. Also, overall $41.4 \%$ of the population reported multiple ethnic origins.

\section{Basic Demographics}

Table 1 presents a remarkable, and at times surprising, description of the immigrant population by generation in a variety of countries. On the left-hand side are summary statistics for

\footnotetext{
${ }^{4}$ More generally, immigrants and their offspring are sometimes clustered into a diverse set of, not always mutually exclusive, "communities" other than ethnic ones including: religion, geography (esp., source country), and language (esp., English or other native languages).
} 
adults between the ages of 25 and 54 for European Union countries, with broader age categories for the "traditional immigrant receiving countries" (Australia, Canada, New Zealand and the United States). First-generation immigrants include all foreign-born residents, regardless of age at immigration and/or nationality at birth, and the second-generation are native born distinguished by whether they had one, or two, foreign-born parents. On the right-hand side of the table are complementary statistics derived from the OECD's (2010, vol. V) PISA program, which focuses on children at the level of schooling most common for 15-year-olds. Shares for the combined 1.5 and second-generation are presented in the table since from the perspective of the school system they are quite similar. Despite the differences in the sample definitions, the basic story is very similar across the two.

Perhaps most surprising is that the traditional immigrant receiving countries do not stand out from the others in terms of the share of the population that is second-generation. Of particular note is the United States with only $6 \%$ of the adult population second-generation, although the PISA estimates show that $19.5 \%$ of the children are first or second generation. Illegal immigration is frequently discussed in the United States' context, but the Pew Foundation (e.g, Cohn and Passel, 2011) suggests that this only increases the first-generation estimate by about 10 or $15 \%$ (so at most the first-generation should be roughly 16 or $17 \%$ ), and the effect for the second-generation adults is undoubtedly smaller. However, this relatively modest share for the second-generation is consistent with United States' immigration history. While the migrant flows in the late 1800s and early 1900s were very substantial, immigration, as it did in many other countries, all but stopped with the onset of the Great Depression around 1930. Even when it started to increase again in the mid to late 1940s the immigration rate in 1949 remained at only $0.13 \%$. Following this period, there was a slow and steady increase in the immigration rate, but (ignoring the regularization around 1990, at which time the immigration rate spiked dramatically to about $0.7 \%$ of the population) even in the early 2000s it never exceeded about 0.37\% (Aydemir and Sweetman, 2008). In contrast, the Australian, Canadian and New Zealand population percentages are at least two to three times greater. Overall, the comparison of the shares of adult second-generation immigrants in the United States with the other traditional immigrant receiving countries is dramatic. Moreover, the comparison with many European countries, especially France and Switzerland, is equally so.

Within Europe equally substantial differences can be observed across countries, with Estonia, Switzerland, Luxembourg, and France having substantial prime age second-generation immigrant populations. Except for some Eastern European countries (and France), the share among the 25-54 population of first-generation immigrants is larger than the share of second-generation immigrants, confirming the common observation of increasing flows. Particularly large jumps between the first and second generations - from extremely low first generation levels - can be observed in southern Europe and Ireland where immigration is a very new phenomenon. These observations are largely confirmed looking at the PISA sample of 15-year-olds.

Beyond Europe and the traditional immigrant receiving nations, the findings from the PISA data indicate that there are very few 1.5 and second-generation children in South and Central America. However, a few countries such as Israel and the Chinese province of Hong Kong have an appreciable number of immigrant children in their education systems.

While these headcounts are useful, it is important to distinguish the characteristics of first and second-generation immigrants since they influence the policy and economic implications of the dramatic variation in levels seen in Table 1. In the extreme, although most individuals are defined as immigrants because they have actually migrated, depending upon the definition employed it is possible for a person's status to change not as a result of their own geographic mobility but because of changing political boundaries. The breakup of the former Soviet Union, 
Czechoslovakia and Yugoslavia are particularly relevant on this front. Also, occasionally countries are sufficiently closely integrated that they have bilateral treaties, such as the Trans-Tasman Travel Arrangement, that allows citizens of Australia and New Zealand free movement between these nations including the right to stay indefinitely and obtain employment. In these types of situations there is very little economic integration required of these "immigrants", and there are few differences in the linguistic or cultural norms for either the first or second generation to overcome.

In terms of economic integration, including the transferability of skills and the ability to acquire new (especially receiving-country specific) skills, it is useful to understand the cultural and linguistic distance between the sending and receiving countries. This need not coincide with the geographic distance. Distinctions such as these are particularly relevant to the 1.5 and secondgeneration since the variety of population shares seen in Table 1 do not necessarily reflect the challenges faced by, among others, education systems in addressing second language fluency, or labor market regulators in combating racial/ethnic discrimination.

Although it goes beyond the scope of this chapter, one could imagine creating an index derived from the differences in the proportion of the population that is first and second-generation as seen in Table 1, but which weights each observation according to the "distance" from the host country's culture(s) and language(s). This builds on Chiswick and Miller's (2012, 2005) efforts to quantify the concept of "linguistic distance". To illustrate, children of Portuguese immigrants to Spain need to learn a language that differs from their "home language", but the challenges faced by these children and their Spanish teachers are not nearly as large as they would be if instead those 1.5 or second-generation children were native Mandarin speakers. Casey and Dustmann (2008) highlight these issues pointing to the intergenerational transmission of receiving country language fluency. Given the unique position of English as an international language, host countries where the language of educational instruction is English, or another international language, may find it easier to integrate children into their school systems, and subsequently their labor markets. In the same vein, immigrants and their children who make human capital investments pre-migration are more likely to make ones that are general, as opposed to country-specific. Again, countries with a relatively common language are likely to have a relative advantage.

Dustmann and Glitz (2011) set up a very general cost-benefit framework for evaluating multigenerational investments in skills, with a focus on language acquisition. For our purposes skills (e.g., a particular language) can be thought of as having alternative values in each of three countries: receiving, source, and a third one. This categorization allows immigrants to undertake a cost-benefit analysis that integrates over the probabilities associated with three potential future paths: permanent settlement, return and onward migration. Particular skills might have different values in each of the three locations. Parents and second-generation children may be far more motivated, and expend more effort, to learn a language that is valuable in multiple locations, as opposed to one that is spoken relatively infrequently outside of the receiving country.

Beyond this, some receiving countries may have access to immigrants who are culturally more similar than do others; for example, Norwegians in Sweden, and citizens of the United Kingdom in the traditional immigrant receiving countries. Similarly, countries such as France, the UK, and the Netherlands have colonial links that influence migrant flows and affect pre-migration human capital compatibility. Further, as Liebig and Widmaier (2010) note, it is important to consider whether immigrants are primarily from wealthy OECD countries, or non-OECD or low income OECD countries (in particular Turkey and Mexico are quantitatively important in Europe and the United States respectively), since this is also associated with second generation outcomes. Contrast Luxembourg, with a large 1.5 and second generation population as seen in Table 1 but where less than $5 \%$ of immigrants between the ages of 20 and 29 are from non-OECD or low 
income-OECD countries, with countries such as Austria, Denmark, Germany, the Netherlands, Norway and the United States where more than $90 \%$ derive from non-OECD or low income OECD countries.

Coming back to the variation in headcounts seen in Table 1 , this discussion of linguistic and cultural distance, and of the incentives faced by immigrants regarding their investments in human capital both pre-and post-migration, suggests that headcounts are an insufficient measure of the challenges associated with the economic integration of the 1.5 and second-generation. Receiving country institutions may find it relatively low cost to integrate a very large number of individuals who, for example, already speak the local language. In contrast, those same institutions might find it much more costly to deal with a much lower immigrant share where the linguistic and cultural distance is much greater. In that sense, the information in Table 1 is only the beginning of the story of economic and social integration across the generations.

\section{Theory and Institutions}

To make headway in understanding the intergenerational economic integration of immigrants into receiving developed countries, researchers need to be familiar with both economic theory and a range of relevant institutions. While economic theory is always in development, without some such framework to organize and stimulate ideas, empirical findings are only a collection of isolated facts that do not promote comprehension, have little predictive power, and are of limited value in informing policy discussions. Simultaneously, the institutional contexts in which empirical findings occur affect their interpretation and generalizability. Ignorance regarding institutional contexts can undermine the credibility of researchers' interpretations of their findings, and in some cases lead to gross misinterpretations. Moreover, a key role of economic analysis is to consider the impacts of differences in institutional structures, including public and private sector policy, over time and across jurisdictions.

\subsection{Economic Theory}

We focus on two key streams of economic theory related to the intergenerational economic integration of immigrants into receiving developed countries. The first is the generational version of the seminal "economic assimilation" concept introduced by Chiswick (1978). Second, we discuss the immigration-oriented offshoot of the intergenerational socioeconomic status mobility literature, with foundational papers in the modern literature being by Zimmerman (1992) and Solon (1992). Borjas (1993) translated this latter literature to the migration context, and Borjas (1992) extended the concept to allow for externalities from ethnic communities.

\subsubsection{Economic Assimilation}

Chiswick's (1978) introduction of the concept of economic assimilation focused on individual-level outcomes and is not discussed in detail here since it is addressed elsewhere in this handbook. Nevertheless, it is worth recalling that the most common implementation of the concept in cross-sectional data is an empirical estimating equation that is generically written as:

(1) $Y=b_{0}+b_{I} I m m+b_{s} S+b_{e} E x p+b_{m} Y S M+b_{x} X+\varepsilon$

where $Y$ is an outcome variable such as the natural logarithm of hourly wages or annual earnings, employment status, or social outcomes such as voting behavior. The regressors are: Imm, an indicator variable set equal to one if the individual is an immigrant, and zero otherwise; $S$, a measure or set of measures of schooling; Exp, typically a vector comprising a polynomial or set of indicator variables reflecting work or labor market experience, most commonly estimated as potential work experience set equal to "age minus years of schooling minus 6", although experience is sometimes replaced by age; YSM, years since migration, which is set equal to zero for the native born and, so as to allow for nonlinearities, is typically specified as a polynomial or set of indicator 
variables for various intervals; $X$, a vector of control variables the elements of which are sometimes central to a particular analysis and the interpretation of the regression. The $b$ 's are coefficients to be estimated and $\varepsilon$ is an error term. Fundamental to this specification is knowledge regarding the date of migration (assuming that there is a single such date).

In much work looking at intergenerational integration using cross-sectional microdata the YSM variable in equation (1) is simply replaced by a set of indicator (dummy) variables defining generational membership, as in Chiswick and DebBurman (2004). A common base specification includes up to five such indicators: adult immigrant, child immigrant (1.5 generation), secondgeneration with mother immigrant, second-generation with father immigrant, and secondgeneration with both parents immigrants.

\subsubsection{Economic Assimilation with Cohort Effects}

Borjas (1985) pointed out that in cross-sectional data the years-since-migration profile cannot be identified without an (implicit) assumption regarding potential shifts in the value of the immigrant-specific intercept (i.e., $b_{I}$ ) across consecutive immigrant arrival cohorts. That is, the years-since-migration profile could equally be interpreted as (at least in part) variation in $b_{I}$ across consecutive arrival cohorts. He showed how in a time series of cross-sections (or panel data) the two concepts could be independently identified, and he interpreted changes in the cohort-specific intercepts, frequently referred to as "entry effects", as allowing for shifts in cohort quality. Some researchers, however, subsequently reinterpreted the changing (declining in Borjas's paper) cohortspecific intercepts as an equilibrium outcome reflecting the interaction of two (or multiple) sides of the market instead of assigning all of the effect to changes in supply/immigrant side quality for example, allowing for the possibility of changing employer discrimination (as seen in, e.g., Bertrand and Mullainathan 2004; Carlsson 2010) or changes in the relative earnings of all new labor market entrants (e.g., Green and Worswick 2010), rather than only changes in worker productivity. ${ }^{5}$ More generally, if there is sufficient data across time, cohort-specific slopes as well as intercepts can be identified (e.g., Borjas, 2013). These insights carry over to intergenerational analysis where it is equally impossible in cross-sectional data to identify generational economic integration independent of substantive assumptions. Traditional immigrant receiving countries are likely to find this relevant since the appreciable change in source countries among immigrants in recent decades is being reflected in the second-generation (with a lag), which will undoubtedly generate parameter heterogeneity.

Although not as easily attributed to any individual researcher, an additional shift in practice and interpretation has moved some researchers away from the specification in equation (1) and its cohort-effect extension. In its place, researchers are more likely to estimate models, with or without cohort effects, similar to the more general specifications that allow the estimated rates of return to both schooling and experience to differ for immigrants pre- and post-migration, and also allow the estimates to vary between immigrants and the native born. ${ }^{6}$ These more general specifications (allowing parameter heterogeneity) raise their own identification and interpretation issues, but also provide greater insight. The move to the less parsimonious specification has been driven by at least two empirical trends commonly discussed in immigrant receiving countries. First, some countries have witnessed a decline in the rate of return to pre-migration labor market experience (Aydemir

${ }^{5}$ In part, since the outcomes of the native born can be observed as a baseline, attributing any shift in the intercept term to one side of the market or the other depends on identifying the elasticity of substitution between immigrants and the native born, perhaps conditional on characteristics (such as education and experience) associated with labor market productivity.

${ }^{6}$ Equation (1) in this chapter is a version of equation (4) from Chiswick's (1978) paper, which was a simplification driven by the data he employed. The more flexible model discussed is analogous to his equation (3). 
and Skuterud, 2005; Borjas, 1995), whereas equation (1) assumes a common rate of return in the post-migration labor market for the pre-migration experience of immigrants and that of the native born in conformable years. Second, across immigrants who migrate at different ages, none, some, or all of their education may be obtained pre-migration, and the rate of return to pre- and postmigration schooling may differ. Further, both the pre- and post-migration rate of return to schooling obtained by immigrants may differ from that received by the native born. Of direct relevance to the intergenerational integration literature is the need to allow for differences in the rate of economic assimilation across generations, but also by ethnic groups (or other such categories), which implies the potential for a wide range of differentiated rates of return.

\subsubsection{Intergenerational Mobility}

The fundamental theory of intergenerational mobility is due to Becker and Tomes (1986, 1979), with many of the key issues concerning measurement error and other biases in measurement, particularly lifecycle issues, addressed by Solon (1992, 1989) and Zimmerman (1992). See Solon (1999) for an overview of the early empirical literature that focuses on estimating the intergenerational relationship itself, and Black and Devereux (2011) for one looking at the second phase of the literature that attempts to identify pathways and estimate causal mechanisms of intergenerational transmission.

Adapted by Borjas (1993) to address mobility across immigrant generations, extending the intergenerational mobility framework is nontrivial since the traditional approach assumes that the model is in steady-state whereas the migration decision can be thought of as both a choice variable and an initial condition followed by economic integration. Borjas (1992) extends the basic model in a different direction focusing not on intergenerational mobility subsequent to migration, but on the closely related topic of intergenerational mobility within ethnic (or in principle other, for example, religious) groups where the aggregate group effect takes the form of an externality.

Since the basic models are well described in the literature, we only highlight certain aspects of the versions relevant to intergenerational migration here. Assuming that migrants care about the utility of their offspring, Borjas (1993) shows that a decision to migrate implies that the dynastic utility function including migration exceeds that excluding it. That is, potential migrants select the highest estimated value among estimates of dynastic utilities in their home country and the set of potential countries to which they might immigrate. Migration in this context is a function of the relative rate of return to the migrant's skills across countries and the relative strength of the intergenerational transmission of those skills. If the rate of return to skills across countries is equivalent, then high skilled immigrants will want to reside in the country where skills are most easily transferable across generations. In contrast, low skilled individuals will prefer countries where the skill level of future generations is not highly determined by that of the current generation. It's worth noting that, as is common in the economics literature, Borjas derives his model assuming risk neutral agents with full information (about not only current but future rates of return to skill and rates of intergenerational skill transmission). While both these are clearly simplifying assumptions, we are aware of no research addressing the implications of, for example, tolerances for risk, and the possible intergenerational transmission of the same, for the migration decision and generational integration. It is also worth keeping in mind that this model focuses on the supply side of the market for immigrants, whereas observed outcomes reflect an equilibrium involving the policies of receiving and sending countries as well as technology constraints that affect, for example, the cost of migration.

In the two period intergenerational version with ethnic group level externalities, Borjas (1992) writes down a model in which parents are assumed to maximize a CES utility function over their own current consumption $\left(\mathrm{C}_{\mathrm{t}}\right)$ and their child's skill level one period ahead $\left(\mathrm{k}_{\mathrm{t}+1}\right.$, which Borjas 
terms quality), ${ }^{7}$ where $\rho<1$ and the $\delta$ 's are weighting parameters:

$$
\text { (2) } U\left(C_{t}, k_{t+1}\right)=\left[\delta_{1} C_{t}^{\rho}+\delta_{2} k_{t+1}^{\rho}\right]^{1 / \rho} \text {. }
$$

The key innovation is that the production function for the skills of the child is assumed to be determined by both the parents' skills and those of the community in which the family resides:

$$
\text { (3) } k_{t+1}=\beta_{0}\left(s_{t} k_{t}\right)^{\beta_{1}} \bar{k}_{t}^{\beta_{2}}
$$

where $\beta_{0}$ and s reflects the rate of intergenerational skill transmission, and $\bar{k}$ is the ethnic group average skill level. While both $\beta_{1}$ and $\beta_{2}$ are assumed to be less than one, the sum of the two may be greater than one and it is this sum that determines whether $\bar{k}_{t}$ converges $\left(\beta_{1}+\beta_{2}<1\right)$, or diverges $\left(\beta_{1}+\beta_{2}>1\right)$, across generations.

Empirically, the almost ubiquitous foundation for estimating the intergenerational transmission of socio-economic status mobility is a simple regression of the form:

$$
\text { (4) } Y_{i, t}=a_{0}+a_{1} Y_{i, t-1}+\epsilon_{i, t} \text {, }
$$

where: $Y$ represents an outcome of interest, most commonly some measure of permanent income or educational attainment; $i$ indexes groups or families (e.g., ethnic group or father-son combinations); the $a$ 's are parameters to be estimated; and $\epsilon$ is an error term. Given the structure of this regression, if the variance of $Y$ is constant across generations, frequently referred to as being in steady-state, then $a_{1}$ represents the intergenerational correlation coefficient and reflects the proportion of the economic status of one generation transmitted to the next. In the context of the move from first to second generation it seems unlikely that the variance in, say, earnings would be constant across generations. In this case the estimate, $a_{1}$, is of the population correlation scaled by the relative standard deviations of the two generations. If the standard deviation of $\mathrm{Y}$ is higher for first- than second-generation immigrants, then the regression coefficient is smaller than the correlation. Solon $(2013,1999)$ discusses aspects of the interpretation for this case and others where intergenerational transmission in relatively simple models is too stylized to adequately reflect the activities captured in the data.

In the case where there are ethnic group influences in addition to within-family transmission processes, equation (4) needs to be expanded. Borjas (1992) suggests introducing ethnic fixed effects with time varying coefficients of the form:

$$
\text { (5) } Y_{i, t}=a_{0}+a_{1} Y_{i, t-1}+\sum_{j} a_{j t} E_{i j}+\epsilon_{i, t} \text {, }
$$

where $E$ is an indicator for person $i$ 's membership in ethnic group $j$. Note that even though ethnic group membership is assumed to be constant, its impact is allowed to vary over time. However alternative specifications are also feasible. For example, Chiswick (1988) suggests that the intergenerational transmission parameter, $a_{1}$, might also vary across ethnic groups. ${ }^{8}$

Borjas (1992) points out that a correlation between children's skills and the ethnic group average need not be interpreted as an ethnic externality. Other causes may also play a role including such issues as discrimination, local school quality, and access to educational financing. Further, following Card et al. (2000) it is further worth considering a few examples of the interpretation of coefficients in regressions such as (4), which are sometimes conducted using individual-level,

\footnotetext{
${ }^{7}$ Of course, $k$ need not be interpreted as skills narrowly defined. It could include any productive attribute affecting utility including, for example, social networks.

${ }^{8}$ In his model, ethnic groups are initially identical except for their taste for family size (number of children). The resource constraint of the well-known child quality-quantity trade-off then implies that there are fewer resources available to children in large families, which reduces the value of the intergenerational transmission parameter for larger families.
} 
aggregate group level, or mixed, data. ${ }^{9}$ Consider a regression such as (4) that is estimated using individual level data on fathers and sons, while the true data generating process for the secondgeneration outcome (e.g., educational attainment or wages) is, for example,

$$
\text { (6) } Y_{i, t}=a_{0}^{2}+a_{1}^{2} Y_{i, t-1}^{F}+a_{2}^{2} Y_{i, t-1}^{M}+\epsilon_{i, t} \text {, }
$$

which includes both father's and mother's lagged outcomes. Then, the probability limit of $a_{1}$ from equation (4) is not $a_{1}^{2}$, but:

(7) $a_{1}^{2}+a_{2}^{2}\left[\operatorname{Cov}\left(Y_{i, t-1}^{F}, Y_{i, t-1}^{M}\right) / \operatorname{Var}\left(Y_{i, t-1}^{F}\right)\right]$.

This bias implies, for example, that ethnic groups with greater assortative mating will appear, in equation (4) to have a higher level of educational persistence between fathers and sons. Along these lines, if ethnic group level human capital and/or neighborhood effects play an important role as suggested by Borjas, so that the true data generating process is, for example:

$$
\text { (8) } Y_{i, t}=a_{0}^{3}+a_{1}^{3} Y_{i, t-1}^{F}+a_{2}^{3} Y_{i, t-1}^{G r p}+\epsilon_{i, t} \text {, }
$$

then if equation (4) is estimated the coefficient in that model will be biased with probability limit:

(9) $a_{1}^{3}+a_{2}^{3}\left[\operatorname{Cov}\left(Y_{i, t-1}^{F}, Y_{i, t-1}^{G r p}\right) / \operatorname{Var}\left(Y_{i, t-1}^{F}\right)\right]$.

Assuming $a_{2}^{3}>0$, then (if they exist) ethnic enclave effects or tighter extended family ties resultant from the immigration experience would make the coefficient in equation (4) appear to be larger for second-generation immigrant children than that among generations of the $3+$ generation with the same underlying father-son relationship. Also, a grouped estimation strategy for equation (4) would accentuate this effect, and the interpretation of any intergenerational ethnic group level regression must be adjusted accordingly. A coefficient from the aggregate data version of regression (4) is clearly not a "true" family-level intergenerational relationship, but captures a much broader range of influences. However, the grouping does address issues of measurement error and transitory fluctuations in variables such as earnings.

While approaches similar to that by Borjas (1992) provide substantial insight and have been successful in allowing economists to think about the role of individuals, families, and communities in the intergenerational transmission of labor market outcomes, education and other variables, these approaches rely on relatively strong assumptions for identification. At their root many of the problems are related to Manski's (1993) well-known "reflection problem". To oversimplify, it details the difficulties in econometric identification involved in understanding whether group outcomes and/or behavior causally affect the choices and outcomes of the individuals in that group, or whether it is simply that individuals who are members of a particular group make similar choices as a result of common unobserved characteristics. Although some researchers (e.g., Cattaneo and Wolter, 2012) acknowledge these identification problems, there is yet to be the push in the immigration literature that has occurred, in particular, in the education literature (for a survey see Sacerdote, 2011) to address the identification issues and substantive economic implications of these community or peer effects (though see section 6). Of particular relevance to this survey is that these identification issues are central to understanding many aspects of intergenerational economic integration where many observers interpret ethnic (and other) communities as playing a formative role.

\subsection{Institutions affecting intergenerational integration}

In a broad survey such as this, it is not possible to detail the great variety of institutions that exist across nations and over time. However, it is important to acknowledge the (potential) differential impacts of these diverse arrangements and to consider how they might influence the

\footnotetext{
${ }^{9}$ Not addressed here are the challenges to inference in regressions combining micro- and macro-level data, especially when the number of macro- or group-level clusters is small. See Cameron and Miller (2014) for an overview.
} 
intergenerational integration of immigrants and cause markedly different outcomes across countries, or within countries across policy regimes. Despite very useful research to date, this is a topic in need of attention.

Clearly, all of the institutions and policies that affect first generation immigrants also affect second generation ones by virtue of the (indirect) transmission mechanisms discussed in section 4.1. However, some of the same institutions and policies also have direct implications for the second generation, while others primarily target the second and subsequent generations. Although any typology is limiting, and ours is not exhaustive, we consider five broad categories of policies and institutions. We provide selected references to published research to illustrate ideas in this section, but we limit the number since our goal is to introduce a simple typology that can be employed subsequently in discussing the broader literature.

First, immigrant selection is clearly central to the outcomes of both first and second generation immigrants. At the broadest level, although there is some overlap, it is worthwhile distinguishing between refugee flows, family reunification, and skilled or economic migration and to recognize how the mix varies across nations and time periods. Additionally, inasmuch as governments are able to execute controls and there is no coercion of families, selection is normally a two-sided process with immigrants choosing among alternative potential destinations. Therefore, the distribution of immigrants across classes within each country reflects an equilibrium. Also, governments are sometimes thought to take "high" (e.g. Australia and Canada) or "low" (e.g. Germany) skills routes in immigrant selection, or to emphasize family reunification (e.g. United States) over skill selection. Aydemir and Sweetman (2008) perform a counterfactual exercise comparing Canada and the United States, predicting the average education level of the future second generation as a function of the current first-generation assuming that the current structure of intergenerational education transmission is maintained. Canada's increasingly high skills route is predicted to increase second-generation educational outcomes appreciably (by about 1.5 years). In contrast, essentially no change is predicted for the United States (an increase of 0.09 years for men, and a decrease of 0.16 years for women), which is consistent with its relatively stable familyoriented selection policy.

Despite this illustration of the potential benefits from taking a high skilled route due to the intergenerational transmission of skills, relatively little research has formally linked immigrant outcomes across the generations to immigration classes. Moreover, the calculus is not as straightforward as it might first appear. Aydemir and Robinson (2008) illustrate that the rate of immigrant departures (onward and return migration) from Canada varies dramatically across immigration classes. Refugees are most likely to stay in the receiving country, economic/business immigrants most likely to depart, with family class immigrants in between - this clearly has important implications for the second generation.

The second broad policy category is the delivery of immigrant settlement services. This includes, but is not limited to, domestic language training, job search assistance for new immigrants, and other formal and informal mechanisms by which immigrants settle into a new society and labor market. It seems likely that most settlement services only impact second and subsequent generations indirectly, via intergenerational transmission. We are aware of relatively little economic research looking at the impact of alternative approaches to settlement services on first-generation immigrants, never mind second-generation ones.

Our third broad policy category has a direct, as well as an indirect, impact on the second and subsequent generations. It encompasses cultural and social attitudes and, if enforced, related formal measures such as multiculturalism and/or anti-discrimination legislation, and requirements such as the 2007 Dutch 'Law on the integration of immigrants' directed primarily at immigrants, 
and obliging them to integrate into Dutch society. These attitudes and policies may have appreciable impacts on the outcomes of second-generation immigrants. Closely related are regulations regarding access to citizenship and political participation. Social cohesion, labor market discrimination, and even such issues as perceptions regarding the value of investments in human capital may all be affected. In looking at the evolution of ethnic minority earnings gaps across the immigrant generations, Skuterud (2010) observes that relative earnings increase across subsequent generations of minority, but not white, male immigrants. Although he continues to see a modest minority earnings gap for third and higher generations, he interprets some of the gap observed for, especially, first-generation immigrants as reflecting not discrimination regarding outward and visible characteristics, but social and cultural gaps with labor market ramifications that are eliminated across the generations. A broadly similar conclusion regarding the importance of "acculturation" is arrived at by Schaafsma and Sweetman (2001) studying the first and 1.5 generations.

Fourth, the openness of the education system to new immigrants and its accommodation of diverse ethnic and linguistic groups is a key policy area. This is central to the development of the 1.5 and subsequent generations since the education system is commonly viewed as one of the most important institutions for both social mobility and labor market success. Dustmann et al. (2012) show that, on average, immigrant children in most European countries have statistically and economically significantly lower OECD PISA test scores than do the native born in those countries. In contrast, Australia, Canada, the UK and the United States have (across the various econometric specifications) very small negative, zero or even positive gaps. Some of this may have to do with "linguistic distance" (discussed in section 3), and related issues, but it may also reflect the structure of the institutions.

Lüdemann and Schwerdt (2013) suggest that early tracking of youth in the school system (called streaming in some jurisdictions) can serve as a barrier for immigrant youth. Although not addressing immigrants, Pekkarinen et al. (2009) study a Finnish policy change that reduced tracking substantially and found that it reduced the intergenerational correlation of education. Sweetman (2010) has complementary findings in a comparison of immigrant children in Australia, Canada and the United States using data from the Third International Math and Science Survey (TIMSS). He observes a "catch up" with age in test scores for students whose parents do not speak the language of instruction at home, but little impact of years since migration beyond the first year. In accord with this, the OECD's (2012) PISA shows mostly similar years since migration profiles across numerous countries. However, since the TIMSS data sample at multiple ages, they permit a broader picture showing that as youth age the impact of not speaking the language of instruction at home diminishes. Potentially, the linguistic and other influences of their home become less important, which accords with Lüdemann and Schwerdt (2013) contention about the problems associated with tracking immigrant youth too young - before they have had an opportunity to overcome their receiving country linguistic deficits.

Fifth, business practices can have substantial impacts for the integration of immigrants across the generations. Although some notable issues, such as foreign credential recognition, primarily affect the first-generation, many other aspects of employers' human resource and other practices directly impact the 1.5 , second and subsequent generations. For example, in one insightful approach a series of papers have investigated racial/ethnic discrimination in hiring practices in the United States, Canada and other countries (e.g., Bertrand and Mullainathan, 2004; Oreopoulos, 2011). Looking at this issue for Sweden, Carlsson and Rooth (2007) sent applications to employers with vacancies in twelve occupations and two cities, Gothenburg and Stockholm. Applications with identical skills were randomly assigned Swedish names and Middle-Eastern names. They find that, 
on average, 29 percent of the applicants with Swedish names got a callback for an interview, while for only 20 percent of the applicants with Middle Eastern names received one. The authors were able to relate the callback rates to employers and recruiters. They found for example that female recruiters are less likely to discriminate, while in small firms and occupations with many immigrants discrimination is more likely to occur. Carlsson (2010) extends the idea by focusing on first- and second-generation immigrants, finding no difference in recall rates to a job interview.

While focusing on the first generation, Aydemir and Skuterud (2008) look at closely related issues. Using matched employee and employer data, they find that immigrants are non-randomly allocated across establishments and that across, rather than within, establishment wage gaps are the major component of the overall native born-immigrant wage differential. Clearly, understanding the mechanisms by which workers are distributed across firms is important for the second generation, especially since in a very interesting study Corak and Piraino (2011) explore the intergenerational transmission of employers and observe that around $40 \%$ of Canadian males at some point work for at an employer for which their father also worked. Further, about $10 \%$ have the same employer in adulthood.

\section{$5 \quad$ Education}

Educational attainment is normally measured in completed years of school, certifications attained, or some other measure of quantity, and is viewed as a central indicator of earnings potential and numerous other benefits. However, as pointed out by, for example, Hanushek and Woessmann (2008) and shown to be relevant for immigrants by $\mathrm{Li}$ and Sweetman (2014), substantive skills are at least as important as measures of educational attainment, since - especially in international comparisons - the latter frequently serve as imperfect proxies for the skills that affect outcomes of interest such as labor productivity and economic growth. We, therefore, address educational attainment in subsection 5.1 and turn to educational performance, that is, skills as measured by test scores, in section 5.2. The two approaches to measuring educational success are also discussed in the following subsections, although almost all existing research focuses on one or the other and does not directly contrast the two by immigrant generation. Nevertheless, those studies focusing on test score gaps among students within a particular academic level by generation, and sometimes by ethnic group, address this issue.

\subsection{Educational attainment}

Table 2 presents measures of educational attainment for the prime age population across the immigrant generations. It includes information for most European countries, as well as Canada, New Zealand and the United States. Educational attainment is grouped into low, middle and high, with the percentage of each generation within the low and high classes presented. Low education is defined as below ISCED 3, or in the North American context less than a high school diploma. Higher education is ISCED level 5 and above, that is, a two year (or community) college, a university bachelor's degree or higher. The middle, omitted, group comprises ISCED 3 and 4, that is, high school graduates and those with post-high school non-tertiary certification. Following Eurostat, ISCED category $3 \mathrm{c}$ is included in the low education group; it includes, from a North American perspective, those with a post-secondary apprenticeship/certificate from a program not requiring high school completion. ${ }^{10}$

For most countries Table 2 indicates that immigrants have the lowest educational attainment, more (or sometimes approximately equally) likely to be in the low education group

\footnotetext{
${ }^{10}$ In practice, the classification of individuals into these categories is not exact and care must be taken in making comparisons in levels. This is less likely to affect patterns across immigrant generations within countries.
} 
than natives and second-generation immigrants. However, there are exceptions, such as Ireland, where natives are quite likely to have low levels of education, and Portugal, where both patterns are reversed. Among the second-generation there is remarkable heterogeneity regarding whether those with one or two foreign-born parents are more or less likely to be in the low education category.

Looking at the other end of the educational spectrum, among the highly educated there are sometimes stark differences between the native born, first-, and second-generation within countries. However, there is no obvious pattern across countries regarding the relationship between the educational attainment of the first generation and native born populations. Although one of the two second-generation categories, and especially that with mixed native and immigrant parentage, is more likely to have the highest share of the highly educated, this relationship is far from universal. Some countries, such as Canada, Ireland, and Poland have remarkably highly educated first-generation immigrants, while in others, notably Italy and Greece, the reverse is the case. Policy, the two-sided immigrant selection process, and institutional features give rise to very substantial heterogeneity in generational educational attainment across nations.

Related to educational attainment, it should also be noted that post-World War II immigration has been primarily urban, and in many countries focused on a few major centers. Since educational attainment is frequently substantially higher in these major cities compared to the rest of each nation, comparisons between immigrants and the native born that condition, or do not condition, on place of residence can produce appreciably different educational gaps.

\subsection{Educational performance}

Table 3 presents information on educational performance, as measured by the OECD's $(2010$, V) PISA program for the combined 1.5 and second-generation compared to the native born. Average scores vary appreciably across countries, but the immigrant performance gap - the average native score minus the average immigrant score - allows informative comparisons. It shows immigrants having lower scores in most countries, especially the European ones. However, the traditional immigrant receiving countries and the United Kingdom tend to have smaller or even negative gaps, although a few other countries (especially Hong Kong, Israel, and Hungary although the latter has relatively few immigrants in school) also have quite small or even negative gaps. It seems plausible that those countries with an established tradition of immigration and/or a strong English speaking presence have immigrant children with higher performance, although establishing a high, in contrast to a low, skills national immigration policy - exemplified by Australia, Canada and New Zealand's point systems - also likely plays a role.

The right-hand side of Table 3 looks at the percentage of immigrants who do not speak the language of the assessment at home. This gives some sense of the challenge faced by the school system in educating immigrants from diverse backgrounds. However, in multilingual countries such as Belgium, Canada and Luxembourg it also points to heterogeneity within the domestic linguistic environment. Hence, in some countries the percentage not speaking the language of the assessment exceeds the percentage immigrant. Again, there are dramatic differences across countries, although uniformly those not speaking the language of the assessment at home have poorer outcomes pointing to the challenges of a linguistically diverse classroom for equality of outcomes. But, many of the aforementioned countries with small, or even negative, scores achieve these egalitarian outcomes despite an appreciable percentage of the immigrant population speaking a language other than the language of the assessment.

\subsection{Age at immigration}

Economists have come to understand the importance of age at immigration for educational attainment and broader issues of economic integration for both immigrants and their offspring. 
Early economic research by Borjas (1995) and Friedberg (1993) considering age at immigration focused on its role, if not appropriately taken into account, in biasing estimates of economic integration (years since migration) profiles estimated in cohort models as discussed in section 4.1.2. In cohort studies based on repeated cross-sections, as opposed to true longitudinal data, addressing age at immigration is relevant because procedures commonly employed for constructing a sample for analysis induce a correlation between the year of immigration and age at immigration. To be of working age and therefore in the sample, the earliest cohorts must have immigrated as children, and the most recent cohorts must have arrived as adults.

Subsequent studies by Schaafsma and Sweetman (2001) using Canadian data, and Chiswick and DebBurman (2004) and Gonzalez (2003) using American data, have expanded scopes and focus on differentiating between the first and 1.5 generations, addressing issues directly related to age at immigration. In terms of educational attainment their results are consistent. In particular, they all observe that in regression models where the dependent variable is a measure of educational attainment, and age at immigration is an independent variable, low order polynomials in age at immigration (e.g., age at immigration and its square) over-smooth the relationship. Allowing for more flexible functional forms shows that immigrants who arrived in their teenage years had lower educational attainment than either those who arrived younger or older.

Schaafsma and Sweetman (2001) posit that those who arrive near the end of high school an important educational transition - experience an educational shortfall since they have insufficient time to recover from the negative entry effect prior to high school completion. Those who arrive at an older age are likely to have completed their education prior to immigration and have high levels of schooling by virtue of Canada's high skills immigrant selection policies. A deficit of over one year of schooling is observed for those who arrived in this trough. Those arriving during this age range are both less likely to graduate high school, and conditional on graduating high school, less likely to attend university. Without controlling for education, a similar trough is observed for earnings as a function of age at migration, but in a regression context once controls for education are included the earnings deficit is eliminated. More broadly, a reduction in the rate of return to education with increasing age of migration is observed with those among the 1.5 generation who arrive before their teen years having an equal or slightly higher rate of return to education than the Canadian born.

Looking beyond the 1.5 generation, Chiswick and DebBurman (2004) observe that secondgeneration American adults have higher average levels of education than do both first-generation immigrants and the $3+$ generation, which is consistent with the findings of Card (2005). However, for two of the largest ethnic groups in the United States appreciable differences in intergenerational integration are observed. While the first-generation educational deficit of Hispanics shrinks in subsequent generations that for Blacks remain stable. Gender differences are also observed with female immigrants having an initial educational deficit of about half the year of schooling relative to their male counterparts, but this gap closes across the generations.

\subsection{Language, starting with age at immigration}

Developing receiving country language skills is an extremely important part of intergenerational immigrant integration. Although this topic extends beyond age at immigration, the connection between immigration age and language development is crucial for the 1.5 generation. Bleakley and Chin $(2008,2004)$, using data from the United States, made critical strides in recognizing the economic implications of this relationship. That language acquisition is a central feature of immigrant social and economic integration is well understood, but they employed age at immigration as part of an identification strategy - in the context of instrumental variables regression - using immigrants from English-speaking countries as a comparison group. Bleakley 
and Chin build on what cognitive scientists label the "critical period hypothesis" whereby children exposed to a new language during the critical period become fluent relatively easily, whereas those exposed later have much less certainty regarding attaining fluency. English language ability among those who arrive before the early teen years is almost identical for immigrants from English and non-English speaking backgrounds. However, the proficiency of those from non-English-speaking backgrounds drops off appreciably as age at immigration increases beyond this threshold. They appear to have identified a key causal mechanism driving the results observed in the literature discussed above: "Better English-language skills induce immigrants who would otherwise drop out with the equivalent of junior high or some high school education to at least complete their high school degree" (Bleakley and Chin, 2004, p. 493).

A number of researchers explore the heterogeneity in age at arrival in more detail, or look at various aspects of it, although not in a causal framework. Van Ours and Veenman (2006) present evidence that immigrant educational attainment indeed depends on age at immigration in The Netherlands. Immigrant children in the 1.5 generation who arrive at a young age are indistinguishable from second-generation immigrants, although the age threshold depends on gender and country of origin. Notably, they observe a gap in outcomes between those immigrating from former Dutch colonies and others. Although this represents a bundle of issues including language, institutional structures, and culture that are difficult to disentangle, as with other research it suggests that obtaining receiving country relevant human capital pre-migration improves postmigration educational integration. In short, source region matters. Corak (2012) seeks to pinpoint the onset of the critical period in terms of high school graduation probabilities using the large samples available from Canadian census data and taking into account country of origin and the associated linguistic distance with Canada's two official languages (English and French). He finds no observable turning point for those children emigrating from countries speaking one of the official languages, and the linguistic distance does not affect the location of the turning point, although it does affect the probability of high school graduation. For those who do not speak English or French at home there is an effectively flat profile prior to age nine, but declining outcomes subsequent to those for non-native language speakers. The magnitude of the effect is remarkable and it is precisely estimated given the large samples in the census (and it is also replicated across many independent national samples). For men (women) from all source countries, 1.5 generation immigrants who arrive by age nine have about a 15 (12) percent chance of not completing high school. In contrast, for both sexes, about 24 percent of those who arrive at 16 or 17 years of age do not complete high school. For non-English speaking immigrants the gap is typically much larger, although the thresholds can vary. For example, male Portuguese immigrants who arrive before age five or six have a just over 25 percent chance of non-completion, whereas for those who arrive between 15 and 17 the percentage is about 60 to 70 .

Böhlmark (2008) observes an age at immigration profile consistent with the literature to date, but he exploits Swedish register data that permit within-family variation to be used as a source of identification. Perhaps surprisingly, in comparing across specifications he finds that siblingdifference, and simple cross-sectional, models have remarkably similar results. Like Corak, he observes a critical age of approximately nine. However, this threshold is not universal; Bratsberg et al. (2011) point to age seven for non-OECD students in Norway, and all find variation in the profiles as a function of "source country". This latter is a consistent theme. The bundle of characteristics represented by "source country" has an appreciable association with outcomes. While some research looking at colonial or other institutional and linguistic ties, and linguistic distance, is starting to provide insights into this rather blunt classification, much remains to be done. 
Overall, it appears that the young age turning point is not driven by educational transitions. Although the probability of high school non-completion increases the closer is the immigration age to the normal age of graduation, and this may influence the slope of the gradient beyond the turning point, the shift from a flat profile to an increasing one seems to reflect the cognitive development aspect of the critical period hypothesis.

Turning from a focus on attainment to achievement (from years of schooling to test scores) Heath and Kilpi-Jakonen (2012) compare several countries using three rounds of the PISA data. Small samples of immigrants in many countries require them to employ parsimonious specifications and they elect to model the natural logarithm of age at arrival - sometimes interacted with source country - as the key independent variable, which means that inflection or kink points cannot be observed. A key benefit of their data, however, is that the authors can study outcomes related to the relative quality of education in the source and receiving countries, which raises issues relevant to age at immigration because of the cumulative growth of gaps in skills. Children moving to, for example, high-quality education systems from low quality education systems seem to accumulate larger deficits with increasing age at migration.

Worswick (2009) confirms many of the findings discussed above by noting that the children of immigrant parents (both 1.5 and second-generation) in the Canadian system have low performance on vocabulary tests at ages four to six regardless of the language of their parents. But, using longitudinal data, he also observes that the average performance of these same children on reading and mathematics tests by age 14 is indistinguishable from that of the native born if their parents speak the domestic language, and it is actually higher when neither parent speaks the receiving country language. It is unclear to what degree these positive results are attributable to the Canadian institutional framework, but it is worth noting that the nation pursues a high skilled immigration selection policy, has active settlement services for both adult and child immigrants, and has very little educational tracking in the early grades.

In accord with Worswick's findings, Dustmann et al. (2010) find that both 1.5 and second generation immigrant children outperform the native born in terms of educational achievement. This is surprising since just before the start of primary school, immigrant children under-perform in early cognitive tests. The authors attribute the improvement of immigrant children during school to the language spoken at home. While non-English immigrant students start with a deficit, once at school it is not only eliminated but reversed. For immigrant children for whom the language spoken at home is English the improvement of educational achievement is substantially less. Wilson et al. (2011) find similar results for state school students in England. Here too, immigrant students make greater progress at school than natives.

Taking an ethnic perspective, and focusing on disadvantaged second generation students using the British Cohort Study 1970, Meunier et al. (2013) find heterogeneity in test results as the students aged. While children born to both South Asian and Afro-Caribbean parents had notable disadvantages in primary school, the relative outcomes of South Asian students improved in later education whereas those for students with Afro-Caribbean parents remained stable. This suggests that ethnic or community norms, as well as intergenerational expectations within the family, may play an extremely important role. These ethnic differences prompted Finnie and Mueller (2010) to highlight related issues, especially parental aspirations, which seem to more than compensate for first generation parental educational deficits and prompt educational attainment that is above the national average (see also Christofides et al., 2008).

One additional observation in Worswick's (2009) study that is also found in Danish research by Nielsen and Rangvid (2012), and Australian work by Chiswick et al., (2005) is that students' test score increase with the parents' years since migration (presumably proxying for economic, 
linguistic and cultural integration). However, the child's own years since migration beyond the first year or two do not seem to affect the child's outcomes. This suggests an important avenue for the intergenerational transmission discussed in section 4.1.3 to affect both educational attainment and achievement.

Using a clever identification strategy, Bleakley and Chin (2008) push the intergenerational transmission idea beyond correlational effects. They demonstrate that an echo of age at immigration, combined with the critical period for language acquisition effect, can be observed among the second-generation. Their work is motivated, in part, by the observation that roughly half the children in the United States public school system who are classified as having limited English proficiency are American born, with most being the children of immigrants. Pursuing an empirical strategy that uses parents' age at immigration as an instrument for parental (and presumably household) English language skills, they observe that parents' English language proficiency has a causal impact on that of their children prior to middle school but then dissipates - again suggesting that the influence of family domestic language ability diminishes with the age of the child. It seems that cumulative exposure to the domestic language, in the formal education system and/or by less formal social interactions, allows 1.5 and second generation youth with initial linguistic deficits to develop language skills at a rate that, consistent with Chiswick's immigrant assimilation hypothesis, exceeds the rate of the $3+$ generation. This remarkable performance may be stimulated by parental aspirations. Nevertheless, the initial deficit causes second-generation children of parents with poor language skills to be more likely to drop out of high school and repeat a grade. Clearly, language is one of the key elements of the source country "black box".

While many aspects of the relationship between the economic integration of immigrants across the generations and language are discussed with respect to age at immigration, a number of studies addressing intergenerational language issues are not directly tied to that concept. Looking across several OECD countries using the OECD's PISA data on 15 year olds, Dustmann et al. (2012) compare the educational gap between second-generation immigrant children and native children. While several parental characteristics are important determinants associated with the educational gap, speaking a foreign language at home is the single most important predictor. Chiswick et al. (2005) confirm many of the observations made to this point. Additionally, and in accord with Dustmann et al., using Australian data on families they point out the large positive correlation in the unobserved determinants of language proficiency among siblings and between children and their parents.

\subsection{Country of destination, mixed marriages, and related issues}

Members of the 1.5 and second generations have educational attainment and achievement differentials that vary from large and positive to zero to large and negative across countries. The negative gaps, where the second-generation have lower educational attainment, are more likely to occur in Europe, and positive gaps are more likely to occur in the traditional immigrant receiving countries. While the sources of this remarkable diversity in outcomes across nations are not fully understood, some pieces of evidence are accumulating suggesting that there is not a single encompassing explanation.

Aydemir and Sweetman (2008) contrast the marked differences between the United States and Canada. In the United States (controlling for age and looking at each sex separately) both the first and 1.5 generations have appreciably fewer years of schooling than does the $3+$ generation with the deficit for adult immigrants being about three times larger. In contrast, in Canada both of these generational groups have about one additional year of schooling relative to the $3+$ generation. However, in both countries second-generation immigrants have greater educational attainment than the 3+ generation, although the size of the gap is appreciably larger in Canada. In Europe the 
second-generation has inferior unadjusted educational outcomes to the $3+$ generation in most countries as seen in, for example, Table 3. However, for France at least, Belzil and Poinas (2010) show that while second-generation immigrants do worse in educational attainment, this gap is mainly explained by differences in parental background. Once these are accounted for the differences are small. In part, immigrant selection seems to play a role in these findings. Further, Schnepf (2007) conducts a cross-country analysis and studies differences in math and reading test scores between the native and immigrant children in each country. She finds that immigrant children score less than the native children, but not all estimates suggest statistically significant differences in the test scores between the two groups. Colding et al. (2009) study the educational progression of second-generation immigrants and immigrant children in Denmark, finding that family characteristics and age at immigration are important determinants of the observed gap in educational attainment.

It matters for the educational attainment of second-generation immigrant children whether both parents are foreign-born or the parents have a mixed marriage in which one parent is native born. When Aydemir and Sweetman (2008) divide the second-generation into those with only the mother, only the father, or both parents immigrants, then having a native born mother is a modest advantage for Americans. Again, in contrast, in Canada the second-generation with two immigrant parents has somewhat greater educational attainment. Looking exclusively at the United States, Card (2005), and Card et al. (2000) find very similar results, but the latter note that the secondgeneration originating from Mexico and the rest of Latin America have, on average, much lower years of schooling - lower than that of the $3+$ generation and the second-generation from other source countries. Chiswick and DebBurman (2004), and Ramakrishnan (2004), find that secondgeneration immigrants in the United States attain more years of education if their parents have a mixed marriage. However, Furtado (2009) finds that having an American born mother has a negative effect on the educational attainment of children. Children with a foreign born father and a mother born in the United States have a higher high-school dropout rate than children from a foreign born mother and an American born father or two foreign born parents. One plausible explanation is that variation in first generational educational aspirations for their progeny is a key driver.

In Europe, mixed marriages also influence the educational attainment of second-generation immigrant children. Van Ours and Veenman (2010) explore the effect of interethnic marriages on the educational attainment of Moluccan immigrant children. Shortly after the end of the Second World War there was a boat-lift of Moluccans from Indonesia to the Netherlands. The Moluccan immigrants were randomly distributed across the Netherlands. Van Ours and Veenman (2010) exploit this random variation to account for possible selectivity in marriage formation. They find that children born from Moluccan fathers and native mothers have a higher educational attainment than children from two immigrant parents or children from a Moluccan mother and a native father. Ohinata and van Ours (2012) investigate the differences in test scores between immigrant children in the Netherlands and native Dutch children conditional on personal and family characteristics and the classroom environment. They also highlight the differential educational achievements by first and second-generation immigrants. They find that immigrant children aged 9 and 10 perform worse in terms of science and math test scores compared to native Dutch children whereas almost no significant differences are found for reading test scores. The negative performance is observed particularly among the 1.5 generation. Only if their parents have a mixed marriage (i.e., marriages in which either the mother or father is native Dutch) does this worse performance disappear. Age at immigration is particularly important for immigrant children born from homogeneous ethnicity immigrant marriages. Increasingly negative educational achievements are observed the later these 
children arrived in the Netherlands. Although not firmly established, the global pattern suggests that, on average, domestic-migrant marriages provide the second generation with improved educational outcomes compared to those from immigrant-immigrant marriages when one parent is from an ethnic group with typical outcomes below the domestic norm, but a disadvantage for those from ethnic groups with outcomes above that norm. A similar pattern is observed at the national level as can be seen by comparing nations such as Canada where second generation immigrants have, on average, relatively good educational outcomes to many European nations where this is not the case.

Sometimes, the disadvantaged educational position of second-generation immigrants is related to the educational system. Krause et al. (2012) compare the educational attainment of second generation immigrants and natives in Germany. They find that second-generation immigrants are disadvantaged before entering the educational system and are further disadvantaged by the system. Natives with an initially disadvantaged position face similar problems. Rather than a migrant-specific problem it is argued to be a general problem of the German educational system. Related to this, Lüdemann and Schwerdt (2013) find that in Germany, conditional on their achievement tests and general intelligence, second-generation immigrant students receive worse grades and teacher recommendations for secondary school tracks.

\subsection{Intergenerational mobility}

Substantial variation in the intergenerational transmission of educational attainment is observed across countries for national populations. Hertz et al. (2007) generate a consistently defined set of parent to child schooling correlations for 42 national populations, that is, without addressing immigrant generational status, and find values as high as 0.66 and as low as about 0.3 across a range of developed countries. In their survey, Black and Devereux (2011) interpret the evidence as being consistent with the theory in that the correlation tends to be higher in jurisdictions where the return to education is higher, and lower where there is greater public spending on education. Further, similar to some of the findings addressed here, they note that later tracking (educational streaming) in the school system decreases intergenerational persistence as does an earlier school start age. However, the vast majority of the variation remains to be explained.

Focusing on immigrants, there appears to be a similarly wide range of intergenerational correlations across countries, although the techniques brought to bear on the question vary across studies and there appears to be no one analysis that applies a consistent methodology across countries so exact international comparisons appear not to exist. Nevertheless, in many countries there is evidence that the educational attainment of the 1.5 and second generations is much less closely associated with that of first-generation immigrants than is the case across generations of the 3+ generation. Comparing across the decades for the United States, Card et al. (2000) observe using data from the 1940s, 1970s and the mid-1990s that in each of the years immigrants have lower average educational attainment than the $3+$ generation, but that the second-generation (with the exception of women in the 1970s) have educational outcomes that are comparable to the 3+ generation. In effect, between the first and second-generation, immigrants "catch-up" and eliminate the educational deficit of the first-generation. Using data for the late 1990s and early 2000's and controlling only for age, Card (2005) finds that the second-generation in the United States not only catches up but surpasses the $3+$ generation.

In the Netherlands, van Ours and Veenman (2003) find the evidence that the gap in educational attainment between with the third generation is smaller for second-generation immigrants than the first-generation. Similarly, Algan et al. (2010) compare the educational attainment of immigrants in France, Germany and the United Kingdom concluding that immigrant children have lower gaps in education than their parents because the education systems seems to 
integrate the children of immigrants. Other studies, typically looking at earnings and education, that find broadly similar results include: Bauer and Riphahn (2007) for Switzerland, Birrell et al. (2002) for Australia, Dustmann and Theodoropoulos (2010) for Britain, Gang and Zimmermann (2000) for Germany, and Rooth and Ekberg (2003) and Hammarstedt and Palme (2012) for Sweden.

In contrast to most of the studies discussed in this subsection thus far that employ an econometric methodology similar to Chiswick's (1978) economic integration approach discussed in section 4.1.1, Aydemir et al. (2013) employ the regression to the mean approach of the intergenerational mobility literature discussed in section 4.1.3. Using Canadian data they observe results consistent with those discussed thus far. The intergenerational correlation coefficient between the first and second immigrant generations is much smaller than that among generations of the $3+$. In particular, the children of first-generation immigrants with relatively low levels of education appear not to have their educational attainment limited by the relatively low educational attainment of their parents. Gang and Zimmermann (2000) observe a similar phenomenon in examining the educational attainment of immigrants in Germany as compared to the native-born. While immigrants have lower attainment, they find a difference between the native-born for whom parental education matters, and immigrants for whom this is not the case. They argue that for the second-generation, their parents' education is probably not a good proxy for parental influence: the "shock of immigration" eliminates the intergenerational consequences of parental education.

Children, particularly boys, from certain immigrant ethnic groups, in contrast to the average, appear to face challenges in making the same educational progress as those from most ethnic communities. This diversity of outcomes across ethnic groups is observed for many countries and is discussed by, for example, Hammarstedt and Palme (2012) for Sweden. Focusing on achievement as opposed to attainment, Meunier (2011) studies 15-year old children using information on their PISA test scores in reading, mathematics and science literacy. Conditional on many personal characteristics including parental education, second-generation immigrants perform worse than native children while first-generation immigrants perform worse than secondgeneration immigrants. This finding raises questions about the interpretation of the closing of the gap in attainment. It may well be that the substantive content of a year's education is not equivalent between the second and 3+ generations, although more work is needed on this topic.

\subsection{Ethnic Externalities}

As summarized in section 4.1.3, Borjas (1992) is a key paper in adding economic structure to the study of the intergenerational transmission of educational outcomes. Across a wide range of immigrant receiving nations, the lists of ethnic groups with, and without, high levels of secondgeneration educational attainment is quite similar (e.g., Aydemir et al., 2013; Birrell et al., 2002; Bratsberg et al., 2011; Hammarstedt and Palme, 2012). For example, using Canadian data Finnie and Mueller (2009) find that while some of the differences between immigrants and nonimmigrants are explained by differences in parental education, family income and parental aspirations, there remains a substantial source country/ethnic fixed effect. Immigrants from some origins have substantially higher likelihoods of completing university.

\subsubsection{Intergenerational integration at the ethnic-group level}

In many cases, studying the intergenerational economic integration of new immigrant groups into a receiving society effectively means addressing issues of ethnicity. In this context, some research chooses to focus on ethnic group level analyses following "generations" defined not by actual parentage but by intervals of time loosely associated with a biological generation. Using United States data, Borjas (1994) is one of the earliest empirical economic efforts in this vein, and the approach has some advantages since it allows studies to survey much longer time periods than 
would be feasible using available data following individuals. ${ }^{11}$ Moreover, looking at group averages reduces some types of measurement error (see section 4.1.3 and the citations therein, although ethnic attrition as discussed in section 2 is a serious threat), and answers an interesting set of ethnic group level questions. Borjas uses the 1910, 1940, and 1980 censuses to obtain information regarding the nominal first, second and third generations. Interestingly, he observes that even immigrants who arrived around 1900 were substantially more urbanized than the existing $(3+$ generation) population; a pattern that continues to this day. Centrally, he observes ethnic group level educational (and economic) integration, but it occurred at a relatively slow pace needing at least four generations or 100 years for typically sized differentials to be eliminated. Quite similar results to those obtained by Borjas are observed by Card et al. (2000) in looking at intergenerational economic integration in the United States.

Whether this relatively slow pace of educational integration extends to societies other than that in the United States is an important question. The slower the pace of economic integration, the more important is first-generation immigrant selection for producing long-run economic impacts. Dicks and Sweetman (1999) undertake a broadly similar analysis in the Canadian context, but using data from 1971 to 1991, and observe similarly slow convergence.

\subsubsection{Immigrants' educational effects on other immigrants and natives}

One educational issue of relevance to the domestic population is the relationship between the presence of the 1.5 and second generation in the school system and the outcomes of others. Early contributions to this topic are by Betts (1998) and Hoxby (1998) who look at the implications of immigration for United States African-American and Latino students and find some evidence of crowding out in terms of high school graduation and college enrolment. Competition for scarce remedial resources is a key mechanism, and non-minorities are not affected. Borjas (2007) has a broadly similar finding in looking at the possibility of foreign students crowding out native ones in graduate programs in the sense that he finds little effect for the typical student. However, particularly in elite institutions, he observes a negative correlation between the number of foreign students and the number of white male native born students in a university's graduate programs.

More recently, Jackson (2011) and Hunt (2012) returned to the issue of immigrant students potentially crowding-out, or crowding-in, native born students. For high school, Hunt finds both positive and negative causal channels operating, but estimates that the net effect is an increase in high school graduation rates, particularly for African-Americans. Looking at college enrollment, Jackson observes a crowding-in (not crowding-out) effect as a function of state level immigration, particularly if the immigration is low skilled.

Turning from educational attainment to educational performance, Brunello and Rocco (2011) use four waves of the PISA data for 27 countries to see if the size of the 1.5 generation at a national level impacts the achievement (test scores) of the second and 3+ generations. They find a small, but statistically significant, effect. In a comparison of Australia, Canada and the United States, Sweetman (2010), addresses percentage of students in each school who are members of the 1.5 generation, do not speak the language of instruction at home, and have fathers with a university degree. Unlike the United States, in Australia and Canada immigrant children are more likely to have fathers with a university degree than do the native born. For Australia and Canada conditional on the school-level language variable, a higher percent immigration is either statistically

${ }^{11}$ This builds on an older literature, particularly one in American sociology. A key debate surrounds the "Melting Pot" hypothesis whereby ethnic group differences are posited to attenuate relatively quickly across a small number of generations, in contrast to a model in which economic (and cultural and social) ethnic group specific traits endure across numerous generations. 
insignificant or associated with higher test scores. However, if the language variable is excluded the percentage immigrant in the school is associated with decreased test scores. In contrast, in the United States both coefficients are negative.

Gould et al. (2009) use the large influx of Jewish immigrants from the former Soviet Union to investigate peer effects on native Israeli students. After accounting for the potential selection bias stemming from such self-selection of immigrants to particular regions of Israel, they that the strong negative impact of the exposure to the immigrant students diminishes once they address the selection bias, although the results remain marginally significant.

Bui (2012) uses data on fifth grade students from a large urban school district in the Southwest United States and studies how limited English proficient students affect each other's educational outcomes in terms of math, reading and language. Taking school fixed effects into account, she finds that a higher share of limited English proficient students in a cohort leads to an improvement of student achievement, in particular on the math scores. This contrasts with most European studies that tend to find negative correlations without controls and/or taking selection into account, but once adjustments are introduced the correlations are reduced to statistical insignificance. Jensen and Rasmussen (2011) study the immigrant peer effects in Denmark using both the 2000 and 2005 PISA, and Danish administrative register, data. They address the nonrandom allocation of immigrant families to certain regions by using the population size of the residence of children as an instrumental variable. They find that a high concentration of immigrant students in school negatively affects the reading and math test scores of native Danish students even after controlling for the potential selection of immigrants to certain regions. Geay et al. (2013) use data from the British National Pupil Database between 2003 and 2009 to relate the percentage of non-English speaking children aged 12 in England to the educational performance of native children within the same school. A raw correlation suggests that there are negative spillover effects on reading, writing, math scores but these disappear after accounting for differences in school characteristics. Finally, Ohinata and Van Ours (2013) analyze whether the presence of immigrant children in the classroom affects the educational attainment of native Dutch children in that classroom. There is a negative relationship between the share of immigrants in a classroom and the reading, science, and mathematics test scores of native Dutch children. However, once selection into particular schools is taken into account, there is no strong evidence of negative spill-over effects on the test scores from immigrant children to native Dutch children.

Using a much larger administrative dataset, Friesen and Krauth (2011) investigate classroom spillover effects in the Canadian province of British Columbia defining immigrant peers as those who speak non-English languages at home since they have no true measure of immigration status. Numeracy and reading scores of students in the fourth and seventh grade are investigated and endogenous selection of immigrants across schools is addressed by including school fixed effects. Immigrant peers' effects on educational attainment are observed to vary substantially by the immigrant students' language at home. Thus the overall average could be negative or positive across contexts depending upon the relative size of the underlying subgroups.

\section{Labor Market Outcomes}

There is an asymmetry in the study of labor market outcomes between Europe and the traditional immigrant receiving countries. Whereas in both sets of nations there are a large number of studies on the educational attainment and performance of second-generation immigrants, the number of European studies on labor market outcomes is more limited. This may have to do with the fact that in many European countries the population of second-generation immigrants is still quite young. However, there is more research in this area for the traditional immigrant receiving countries, especially regarding the economic integration of Mexican and Hispanic immigrants in the United 
States. Nevertheless, even in Europe the first cohorts of the more numerous recent second generation have entered the labor market, and broadly speaking, the labor market position of second-generation immigrants is closely related to their educational attainment and language skills. Overall, to the extent that immigrants in particular nations do worse or better than natives in terms of education and language they also tend to do worse or better in the labor market. But, as will be discussed, success in education seems to be more easily attained than that in the labor market.

\subsection{Stylized facts regarding labor market outcomes}

The labor market position of immigrants in many European countries is weak; unemployment rates among immigrants are high, employment rates are low (Boeri and van Ours, 2013; OECD, 2011) and this may have an intergenerational influence on the second generation. Table 4 gives a cross-country overview of the labor market position of immigrant children by comparing unemployment and employment rates of 20 to 29 year old children of natives with those of native-born children of immigrants. As the first four columns show, there is wide variation in unemployment rates across countries. However in terms of differences between children of natives and native-born children there are two types of countries. In countries such a Belgium, France, Germany and the United Kingdom there are substantial differences in unemployment rates with immigrant children sometimes having an unemployment rate that is twice as high as the unemployment rate among native-born children. And, there are countries such as Australia, Canada, Norway and the United States where the differences in unemployment rates are small or even absent. The same distinction can be made in terms of average employment rates. In some countries such as the United States, Switzerland and Australia there are hardly any differences while in other countries the differences are substantial. The bottom part of Table 4 shows that the differences in employment rates are mainly present among individuals with low education. For low-educated men, for example, only in New Zealand, Norway and Spain are the differences in employment rates between the second and 3+ generations small, whereas for highly educated men the gaps are mostly small or absent, with the exception of Belgium, Germany, Norway and Sweden.

Table 5 gives information for a few countries about median wages of foreign-born workers relative to native-born. Except for Australia, median wages are lower for foreign-born workers than for native-born ones, the lowest being the U.S. (79\%) and the Netherlands (85\%). However, the median wage differences between native-born and foreign-born are to a large extent due to differences in educational attainment with native-born having a higher educational attainment and thus higher wages. Within broad educational categories wage differences are substantially smaller. Interestingly, relative to the native born immigrants with low levels of education have better wage performance than those with higher levels of education in every nation except Sweden. While we can only speculate, a number of factors may be at play including differing mechanisms for selection into levels of education, national immigrant selection policy, and issues of foreign credential recognition and/or educational quality potentially interacting with other aspects of the portability of educational human capital.

\subsection{Studies addressing labor market outcomes}

A number of studies in the United States and Canada have analyzed the labor market performance of migrants, notably their convergence to wages of natives (Borjas, 1999) and the decline in outcomes for more recent arrival cohorts that may influence the second generation. According to Borjas (1992), ethnic capital - the quality of the ethnic environment in which a person is raised - influences the skills and the labor market outcomes of immigrant children. Thus ethnic capital is an important determinant of intergenerational mobility, and the skills and labor market outcomes of one generation depend not only on parental characteristics but also on the average 
skills of the parents' generation. Analyzing American data, Borjas (1992) finds that assimilation is slow and there is appreciable persistence of earnings capacity across generations. This accords with the ethnic group level analysis of Borjas (1994) that finds on the order of four generations or 100 years is required for ethnic groups to "catch up" in the labor market. Tu (2010) studies the differences in the return to education between first, second and third-generation immigrant men in Canada. His results are consistent with the basic pattern in the United States, although there are differences of degree. He also finds that second-generation immigrants with one foreign-born parent do not perform significantly better than those with two immigrant parents. Skuterud (2010) finds evidence of persistence of earnings differences across generations of immigrants in Canada.

Taking an intergenerational perspective akin to that discussion in section 5.6.3 and extending Borjas (1992), Aydemir et al. (2009) observe higher immigrant earnings mobility in Canada than the United States. Further, in an effort to distinguish between an ethnic externality and other potential constraints, such as discrimination or educational financing, as sources of persistence they conduct quantile regressions expecting the persistence to be observed primarily among those from the upper quantiles of the distribution. This is a comparison of the highest earning children from high earning families to the highest earning children from low earnings families as a test of equality of opportunity across immigrant communities. They find that the least squares results are driven by the upper portion of the distribution. Conditional on father's education, the results are similar for sons and daughters: they observe a marked reversal of intergenerational transmission across the income quantiles with high income children having negative intergenerational coefficients and low income ones having positive ones. While ethnic externalities play a role, there are also influences from other mechanisms such as discrimination and/or credit constraints. Overall, they find that the advantages of one immigrant generation are only weakly passed on to subsequent generations at the ethnic group level. Of course, given the timing of data employed and the focus on adults, it studies only those who arrived prior to the significant decline in the entry earning of new immigrants and it is too early to ascertain if this pattern will continue for more recent arrival cohorts.

One interpretational observation made by Card et al. (2000), Card (2005), and especially by Aydemir and Sweetman (2008), is that there are marked differences in unconditional and conditional labor market outcomes in some countries. Contrast simple earnings regressions, by sex, controlling only for age and immigrant generation. In the United States the second generation with all combinations of parentage is, on average, statistically indistinguishable from the $3+$ generation. In contrast, adult immigrants have substantially lower earnings and the 1.5 generation has a negative gap, but only half of that of the adults. Introducing controls for education, location of residence and ethnicity have essentially no effect on the coefficients for the second-generation, but the negative coefficients of the first and 1.5 generations are reduced by half suggesting that much of the earnings deficit is associated with these variables (Aydemir and Sweetman, 2008). Canada, with its high skilled immigrant selection policy and superior immigrant educational outcomes, provides a useful point of contrast. While adult immigrants have an unconditional earnings deficit relative to the $3+$ generation, though one that is not as large as in the United States, the 1.5 generation, and the second-generation of various parentages (mother only, father only or both parents immigrants), all have statistically significant and economically important earnings premiums relative to the $3+$ generation. Interestingly, having both parents as immigrants provides the greatest premium. However, when education is introduced as a control the sizes of the premiums are diminished. Further, when location of residence and ethnicity are also included in the regression the statistically significant premium changes to a statistically significant, although economically modest, deficit for the second-generation groups and becomes statistically 
insignificant for the 1.5 generation. It appears that 1.5 and second-generation immigrants in Canada, on average, obtain higher levels of education than the $3+$ generation, but they also receive a lower rate of return to that education. Moreover, they tend to be concentrated in high wage urban centers and this accounts for some of the unconditional earnings premia. Centrally, it appears that the children of immigrants have excellent educational outcomes, and while they also have very good labor market outcomes the latter do not keep pace with the former.

In the United States, there is a literature focusing on Mexican and Hispanic immigration across the generations since it is a very significant fraction of immigration to the country. Trejo (2003) observes an appreciable improvement between the first and second generation of Mexican immigrants - particularly associated with improved educational attainment and English language skills, and also an increase in the rate of return to education. However, he observes relatively little movement beyond the second-generation. In contrast, Smith (2003) has more optimistic findings with education, and through it earnings, increasing into the third-generation. Nevertheless, in both cases there is substantial persistence and many generations are required to close the earnings gap. Like much of the subsequent literature, educational attainment is seen as a prerequisite to largescale earnings increases. As mentioned earlier, Duncan and Trejo (2012) point out that ethnic identification is a crucial issue for understanding intergenerational economic assimilation, especially for later generations. They argue that correcting for ethnic attrition raises the standing of later generation Hispanic immigrants. In contrast to the idea of host country linguistic skill being a requirement for intergenerational integration, Lewis (2011) observes that the Hispanic community is sufficiently large in the United States that a Spanish-speaking labor market in which the rate of return to English is quite low has emerged. However, language remains a barrier of sorts since it influences the substitutability of workers across Spanish and English speaking labor markets and may limit earnings growth as pointed out by Borjas (2013). The full intergenerational implications of this trend are not yet evident.

Blau and Kahn (2007) take a gender perspective to intergenerational assimilation. They note that while there is modest assimilation for males, the evidence is more mixed for females. The increasing educational attainment of the second-generation increases wages but is associated with decreases in female labor supply (from a high level) and these two patterns trade off against each other.

Studies on the labor market performance of second-generation immigrants in Europe indicate that educational attainment, ethnic identity, the nature of the marriage of the parents and language skills are important determinants. Rooth and Ekberg (2003) study the labor market position of immigrant children in Sweden. They find that second generation immigrants from Southern and non-European backgrounds do much worse than the 3+ generation. Labor market outcomes are more favorable if one parent - especially if the mother - is born in Sweden, compared to having two immigrant parents. Nielsen et al. (2003) study the school-to-work transition of second-generation immigrants in Denmark finding that compared to 3+ generation Danish youngsters second-generation immigrants search longer for their first job, have first jobs that last a shorter time, and receive lower wages in their first job. There is substantial heterogeneity within the second generation with women facing larger problems. These problems are related to their educational attainment and the labor market integration of their parents. Parents' attitudes on the role of women are important determinants of the labor market success of second-generation immigrant women in Denmark. Van Ours and Veenman (2004) study early labor market experiences of second-generation immigrants in the Netherlands. They focus on the four main nonwestern immigrant groups. From a direct comparison, it appears that especially Turkish and Moroccan immigrant children do not perform as well as native Dutch youngsters. Young 
Surinamese and Antilleans also do worse than their Dutch counterparts, but for them the differences are smaller. When leaving school the average educational level of these ethnic groups is lower, as is their participation in the labor market - and if they participate they are less likely to have a job.

Belzil and Poinas (2010) find that the differences in early employment experiences between second-generation immigrants and French natives are small once schooling and observed characteristics are accounted for. In this context, the probability of accessing permanent employment is virtually the same for second-generation immigrants and native French children. While Algan et al. (2010) conclude that immigrants in France, Germany and the United Kingdom make progress in terms of educational attainment, in that second-generation immigrants perform better than first-generation immigrants, they do not find similarly marked evidence of progress for labor market performance. Ekberg et al. (2010) compare earnings differentials of three generation immigrants and natives in Sweden. They find an earnings advantage of first-generation immigrants compared to natives that reverses to an earnings disadvantage for third-generation immigrants compared to the second -- a result also found by Hammarstedt (2009). Bisin et al. (2011) find that ethnic identity and labor market outcomes of non-EU immigrants in Europe are related. Immigrant children have a higher probability of being employed than their parents and, compared to natives, there does not seem to be any difference in terms of employment. The authors relate this to an economic integration process of immigrants. Lüdemann and Schwerdt (2013) find that a substantial part of the wage gap between second-generation immigrants and natives in Germany is explained by differences in school track attendance. Gorinas (2014) uses Danish data to investigate whether ethnic identity affects the employment position of first- and second-generation immigrants finding that this is not the case.

Casey and Dustmann (2008) point to the importance of the intergenerational transmission of linguistic skill, even after taking into account a large number of socio-demographic factors, using longitudinal German data. One of the advantages of their dataset is that by virtue of repeated measurements on language proficiency, it permits measurement error - which is found to be nontrivial - to be addressed directly. Interestingly, they observe that the parents' level of ability in the receiving country's language is more important for the 1.5 than for the second generation, which is broadly consistent with the earlier observation that the child's language ability is increasing in the parents' years since migration. Moreover, second-generation language proficiency appears only to affect labor market outcomes for females and not for males. The authors posit that in the German labor market males may be able to obtain employment where language skills are less important. Messinis (2009) observes that for the Australian labor market once language is taken into account among the second generation, the disadvantage that is observed in unadjusted analysis is eliminated. This emphasizes the importance of language in the labor market, even for those born and raised domestically, and points to the relevance of pre-market skill development, and inequality in the same, for outcomes.

\section{The evolution of cultural and social outcomes across generations}

Economists have looked at the intergenerational transmission of a variety of cultural and/or social characteristics and outcomes across the immigrant generations. Relevant issues range from health, to fertility, to tastes for redistribution and voting. We survey a limited range of issues.

Looking first at health status, Akbulut-Yuksel and Kugler (2007) find evidence that both natives and immigrants in the United States inherit a substantial fraction of their health status through intergenerational transmission from their parents. This includes their body mass index (BMI), and the probability that they will experience depression and asthma.

In terms of health care utilization, Currie (2000) observes that the children of immigrants 
are far more likely to be eligible for Medicaid coverage than the children of natives. However, take-up rates for immigrant children are substantially lower. Consistent with this, using Italian data De Luca et al. (2013) find that like the first-generation, the second are less likely to make use of medical specialist and telephone consultations than are the $3+$ generation, but they are more likely to use emergency rooms than the 3+. Overall, the second-generation (and in some studies the 1.5 generation) appear to be less likely to utilize healthcare resources, even conditional on health risk factors. From a slightly different perspective, Lillard (2013) looks at the smoking propensity of 1.5 and second-generation United Kingdom (UK) immigrants in the United States, Australia and South Africa to ascertain the role of source country culture as a transmission factor. While UK smoking patterns for each parent's cohort do not predict those of their children in South Africa, they are predictive in Australia and the United States. Interestingly, sons of UK immigrants are influenced by the patterns of both parents' cohorts, while their daughters appear to only be influenced by their mother's cohort.

A central issue in the intergenerational cultural integration of immigrants is interethnic marriage. It is the subject of a large literature surveyed by Furtado and Trejo (2013) and we therefore only highlight a few trends here. Using United States data, Card et al. (2000) explore the relationship between the characteristics of ethnic cohorts from the 1940s and the interethnic marriage rates of their children in the 1970s. They observe that the rate of interethnic marriage increases with the ethnic group average educational attainment of fathers, but is unaffected by income. However, there are a small number of outliers that experience relatively modest rates of interethnic marriage regardless of the parents' educational attainment, particularly Asian ethnic groups.

An issue closely tied to intermarriage is fertility. Blau et al. (2008) look at American data and observe a substantial positive correlation between fertility rates in the first and second generation. Moreover, the correlation with the mother's ethnic group average is stronger than that for fathers. They present evidence suggesting that the intergenerational transmission of gender roles is a key mechanism. Nevertheless, overall there is convergence towards native fertility rates. Fernández and Fogli (2009) seek to identify the mechanisms underlying the intergenerational transmission of fertility rates and find source country/ethnic culture is a key driver. Moreover, they observe that the intergenerational transmission of fertility is stronger among groups that tend to cluster in ethnic enclaves.

Almond et al. (2009) address the fertility-related issue of "son preference" across the immigrant generations using Canadian data. It is well-known that male to female sex ratios are above the biological norm in several immigrant source countries, and the essential issue is whether this preference endures across the immigrant generations in North America. They find the sex ratio to be normal at first parity in the second generation, but to increase for later births if no son has been previously born across the generations of Asian immigrants. Within this broad grouping, they find differences by religious affiliation regarding whether fertility or sex selection channels are employed. Overall, they argue that their findings are consistent with an intergenerationally transmitted cultural preference for boys rather than an economic motivation such as requiring support in old age.

Finally, we address the web of cultural proclivities involving trust, voting and the taste for redistribution, all of which are fundamental to the development of the receiving nation's economic policy. Moschion and Tabasso (2013) compare the transmission of trust to second-generation immigrants in the United States and Australia and find that the level of trust, as they measure it, is indeed passed on to the second-generation. But, the environment also appears to play a role in the transmission process. Intergenerational transmission appears to play a much stronger role in the 
United States, which has much lower background levels of trust, than in Australia. While important on the personal level, ideas of trust are particularly important on the national stage when relevant groups become politically active. Focusing on American politics, Shertzer (2013) finds an inverseU relationship between political mobilization and the share of the local electorate from a particular ethnic group. This is a story of ethnic enclaves that build up across multiple generations providing a political base deriving from scale. In a particularly interesting complementary study, Luttmer and Singhal (2011) illustrate how source country tastes for redistribution - or more broadly economic policy - affect voting patterns among immigrants in the United States and that these tastes strongly persist to the second-generation. In sum, although cultural integration towards the receiving country norms do operate, source country preferences and tastes are clearly visible among the second-generation of immigrants and these influence voting patterns and thereby policies for economic issues such as redistribution.

\section{Conclusion and thoughts on future research}

Migration of persons from one country to the other has been going on for centuries but the direction of the flows has changed in recent decades. Traditional immigrant countries - the United States, Australia, Canada and New Zealand -- are still attracting many immigrants. But, European countries which used to be immigrant sending countries have become net immigrant receiving countries to the extent that the traditional immigrant receiving countries do not stand out from many new immigrant receiving countries in terms of the share of the population that is secondgeneration.

Many specific issues related to the economic integration of second-generation migrants take quite different forms in each country grouping, and in each individual country. Broadly speaking, the children of immigrants in Europe tend to be younger than those in the traditional immigrant receiving countries. However there are also other differences, including: average levels of education, the percentage of the children of immigrants who speak the receiving country language at home, and other similar characteristics. The enormous diversity in immigrant characteristics implies substantial heterogeneity in economic outcomes for second-generation immigrants.

Both types of countries face challenges as young immigrants and the children of immigrants from diverse backgrounds and linguistic groups enter into the education system and integrate into the labor market. There are several policies and institutions that directly affect the economic position of second-generation immigrants, while others primarily affect first-generation immigrants and only indirectly influence the second-generation through intergeneration transmission mechanisms. Immigrant selection is among the most relevant of policies. Whether a country aims to attract high- or low-skill immigrants, or whether it emphasizes family reunification or refugee movements, determines the average educational level of first-generation immigrants and through them the educational attainment of the second-generation. Immigrant settlement services such as domestic language training and job search assistance for new immigrants determine how first-generation immigrants settle in the receiving country and through that the economic position of second-generation immigrants is influenced. A crucial institution that determines the economic future of second-generation immigrants is the education system via the degree of its openness to new immigrants and its accommodation of diverse ethnic and linguistic groups.

There is substantial heterogeneity in educational attainment of second-generation immigrants both between and within countries. In many European countries second-generation immigrants on average do worse than natives while in traditional immigration countries and, perhaps because it is English speaking, the United Kingdom second-generation immigrants on average outperform natives. Important determinants of within-country variation in educational 
attainment of second-generation immigrants are age at immigration, language spoken at home, marital status of the parents, and educational attainment of the parents. Age at immigration typically affects the educational attainment of first-generation immigrants but through that it also affects the educational attainment of second-generation immigrants. Language skills are an important determinant of performance at school and therefore acquisition of the native language is of utmost importance. If a foreign language is spoken at home, second-generation immigrant children may arrive at school with a language deficit and this deficit makes them more likely to drop out of school early. It matters for educational attainment of second-generation immigrants whether both their parents are immigrants or one of the parents is native. Mixed marriages are often beneficial to the educational attainment of the offspring. Finally, although there is substantial persistence in the intergenerational transmission of educational attainment in many countries and among certain ethnic groups, in other nations and for other groups, however, especially the traditional immigrant receiving nations and for immigrants from Asian source countries, parents' educational deficits appear not to hinder remarkable educational attainment among the 1.5- and second-generations.

Compared to the vast number of studies on the educational attainment of second-generation immigrants there is only a modest number of studies on their labor market outcomes. This may have to do with the average age of most second-generation immigrants in Europe, which is not far beyond the age at which individuals enter the labor market. Labor market outcomes, employment, unemployment and wages are to a large extent determined by educational attainment and language skills. Thus, in the traditional immigration countries there are hardly any differences in unemployment rates between natives and second-generation immigrants while in other, mainly European, countries the differences can be substantial. Nevertheless, after accounting for differences in educational attainment and other personal characteristics the differences in labor market outcomes are substantially smaller or even absent.

As to future research, clearly there is a variety of topics that are interesting to explore. A first area of future research concerns the role of institutions and policies affecting intergenerational integration, which is not an easy research area because institutions and policies have the tendency to remain unchanged. This prevents researchers from drawing firm causal inferences on how changes in these policies or institutions affect economic outcomes of second-generation immigrants within countries. Nevertheless, cross-national studies could bear much fruit. A second area of future research concerns the acquisition of language skills. Whereas there are quite a few studies that find that language skills are an important determinant of educational attainment there is not a lot of research regarding what can be done to improve these skills. Early intervention in the acquirement of the language of the receiving country can be beneficial as it may prevent secondgeneration immigrants dropping out of the educational system early. A third area of future research is related to the issue of labor market discrimination. Some, but not all, studies claim that secondgeneration immigrants face discrimination; however, the degree to which, and the contexts in which, this occurs and its empirical magnitude are yet to be established. Fourth, research involving ethnic identity is relevant to better understand the determinants of the speed by which second- and later generations integrate into the immigrant receiving countries. Finally, there is interesting work to be done looking at the demand side of the labor market. In particular, the employee-employer match and the employment relationship for the 1.5 and second generation are only starting to be studied. 


\section{References}

Akbulut-Yuksel, M., and Kugler, A. D. (2007). Inter-generational Transmission of Health Status in the U.S. among Natives and Immigrants. Department of Economics, University of Houston.

Algan, Y., Dustmann, C., Glitz, A., and Manning, A. (2010). The Economic Situation of First and Second-generation Immigrants in France, Germany and the United Kingdom. Economic Journal, 120, F4-F30.

Almond, D., Edlund, L., and Milligan, K. (2009). O Sister, Where Art Thou? The Role of Son Preference and Sex Choice: Evidence from Immigrants to Canada, NBER Working Paper 15391.

Aydemir, A., Chen, W., and Corak, M. (2009). Intergenerational Earnings Mobility Among the Children of Canadian Immigrants. Review of Economics and Statistics, 91(2), 377-397.

Aydemir, A., Chen, W.H., and Corak, M. (2013). Intergenerational Education Mobility among the Children of Canadian Immigrants. Canadian Public Policy, 39(s1), S107-S122.

Aydemir, A., and Robinson, C. (2008). Global Labour Markets, Return, and Onward Migration. Canadian Journal Of Economics, 41(4), 1285-1311.

Aydemir, A., and Skuterud, M. (2005). Explaining the Deteriorating Entry Earnings of Canada's Immigrant Cohorts, 1966 - 2000. Canadian Journal of Economics, 38, 641-671.

Aydemir, A., and Skuterud, M. (2008). The Immigrant Wage Differential Within and Across Establishments. Industrial and Labor Relations Review, 61(3), 334-352.

Aydemir, A., and Sweetman, A. (2008). First- and Second-generation Immigrant Educational Attainment and Labor Market Outcomes: A Comparison of the United States and Canada. Research in Labor Economics, 27, 215-270.

Bauer, P., and Riphahn, R. T. (2007). Heterogeneity in the Intergenerational Transmission of Educational Attainment: Evidence from Switzerland on Natives and Second-Generation Immigrants. Journal of Population Economics, 10(1), 121-148.

Becker, G. S., and Tomes, N. (1979). An Equilibrium Theory of the Distribution of Income and Intergenerational Mobility. Journal of Political Economy, 87, 1153-1189.

Becker, G. S., and Tomes, N. (1986). Human Capital and the Rise and Fall of families. Journal of Labor Economics, 4, 1-47.

Belzil, C., and Poinas, F. (2010). Education and Early Career Outcomes of Second-generation Immigrants in France. Labour Economics, 17(1), 101-110. 
Bertrand, M., and Mullainathan, S. (2004). Are Emily and Greg More Employable Than Lakisha and Jamal? Field Experiment on Labor Market Discrimination. American Economic Review, 94, 991-1013.

Betts, J. R. (1998). Educational Crowding Out: Do Immigrants Affect the Educational Attainment of American Minorities? In D. S. Hamermesh and F. D. Bean (Eds.), Help or Hindrance? The economic implications of immigration for African-Americans (pp. 253281). New York: Russell Sage Foundation.

Birrell, B., Khoo, S.-E., McDonald, P., and Giorgas, D. (2002). Second Generation Australians: Report for the Department of Immigration and Multicultural and Indigenous Affairs (pp. 1148). Canberra.

Bisin, A., Patacchini, E., Verdier, T., and Zenou, Y. (2011). Immigrants and the Labour Market. Economic Policy, 26, 57-92.

Black, S. E., and Devereux, P. J. (2011). Recent Developments in Intergenerational Mobility. In David Card and O. Ashenfelter (Eds.), Handbook of Labor Economics, Vol 4B (pp. 14871541). Elsevier Ltd.

Blau, F. D., and Kahn, L. M. (2007). Gender and Assimilation among Mexican Americans. (G. J. Borjas, Ed.) Mexican Immigration to the United States. Chicago: University of Chicago Press.

Blau, F. D., Kahn, L. M., Liu, A. Y.-H., and Papps, K. L. (2008). The Transmission of Women's Fertility, Human Capital, and Work Orientation Across Immigrant Generations. Journal of Population Economics, 26(2), 405-435.

Bleakley, H., and Chin, A. (2004). Language Skills and Earnings: Evidence from Childhood Immigrants. Review of Economics and Statistics, 86, 481-496.

Bleakley, H., and Chin, A. (2008). What Holds Back the Second Generation? Transmission of Language Human Capital among Immigrants. Journal of Human Resources, 43(2), 267298.

Boeri, T., and van Ours, J. C. (2013). The Economics of Imperfect Labor Markets, Second Edition. Princeton: Princeton University Press.

Böhlmark, A. (2008). Age at Immigration and School Performance: A Siblings Analysis using Swedish Register Data. Labour Economics, 15(6), 1366-1387.

Borjas, G. J. (1985). Assimilation, Changes in Cohort Quality, and the Earnings of Immigrants. Journal of Labor Economics, 3, 463-489.

Borjas, G. J. (1992). Ethnic Capital and Intergenerational Mobility. Quarterly Journal of Economics, 107(1), 123-150. 
Borjas, G. J. (1993). The Intergenerational Mobility of Immigrants. Journal of Labor Economics, $11(1), 113-135$.

Borjas, G. J. (1994). Long-run Convergence of Ethnic Skills Differentials: The Children and Grandchildren of the Great Migration. Industrial and Labor Relations Review, 47(4), 553573.

Borjas, G. J. (1995). Assimilation and Changes in Cohort Quality Revisited: What Happened to Immigrant Earnings in the 1980s? Journal of Labor Economics, 13, 201-245.

Borjas, G. J. (1999). The Economic Analysis of Immigration. In O. Ashenfelter and D. Card (Eds.), Handbook of Labor Economics (pp. 1679-1760). Amsterdam: Elsevier.

Borjas, G. J. (2007). Do Foreign Students Crowd Out Native Students from Graduate Programs? In P. E. Stephan and R. G. Ehrenberg (Eds.), Science and the University (pp. 134-149). Madison: University of Wisconsin Press.

Borjas, G. J. (2013). The Slowdown in the Economic Assimilation of Immigrants: Aging and Cohort Effects Revisited Again. NBER working paper. Cambridge MA.

Bratsberg, B., Oddbjorn, R., Roed, K., and Raaum, O. (2011). Educating Children of Immigrants: Closing the Gap in Norwegian Schools. IZA working paper.

Brunello, G., and Rocco, L. (2011). The Effect of Immigration on the School Performance of Natives: Cross Country Evidence Using PISA Test Scores. IZA Discussion Paper.

Bui, S.A. (2012). How do Limited English Proficient Students Affect Each Others Educational Outcomes? Evidence from Student Panel Data. Discussion Paper University of Houston.

Cameron, A.C., Miller, D.L. (2014) A Practitioner's Guide to Cluster-Robust Inference. Journal of Human Resources, 49, forthcoming.

Card, D. (2005). Is the New Immigration Really So Bad? Economic Journal, 115(507), 300-324.

Card, David, DiNardo, J., and Estes, E. (2000). The More Things Change: Immigrants Chidren of Immigrants in the 1940s, 1970s, and the 1990s. In G. J. Borjas (Ed.), Issues in the Economics of Immigration. Chicago: University of Chicago Press.

Carlsson, M, and Rooth, D. (2007). Evidence of Ethnic Discrimination in the Swedish Labor Market using Experimental Data, Labour Economics, 14, 716-729.

Carlsson, Magnus. (2010). Experimental Evidence of Discrimination in the Hiring of First- and Second-generation Immigrants. Labour, 24(3), 263-278.

Casey, T., and Dustmann, C. (2008). Intergenerational Transmission of Language Capital and Economic Outcomes. Journal of Human Resources, 43, 660-687. 
Cattaneo, M. A., and Wolter, S. C. (2012). Migration Policy Can Boost PISA Results: Findings from a Natural Experiment. IZA working paper.

Chiswick, B. R. (1978). The Effect of Americanization on the Earnings of Foreign-born Men. Journal of Political Economy, 86(5), 897-921.

Chiswick, B. R. (1988). Differences in Education and Earnings Across Racial and Ethnic Groups: Tastes, Discrimination, and Investments in Child Quality. Quarterly Journal of Economics, 103, 571-597.

Chiswick, B. R., and DebBurman, N. (2004). Educational Attainment: Analysis by Immigrant Generation. Economics of Education Review, 23(4), 361-379.

Chiswick, B. R., Lee, Y. L. L., and Miller, P. W. (2005). Parents and Children Talk: English Language Proficiency Within Immigrant Families. Review of Economics of the Household, 3(3), 243-268.

Chiswick, B. R., and Miller, P. W. (2005). Linguistic Distance: A Quantitative Measure of the Distance Between English and Other Languages. Journal of Multilingual and Multicultural Development, 26(1), 1-11.

Chiswick, B. R., and Miller, P. W. (2012). Negative and Positive Assimilation, Skill Transferability, and Linguistic Distance. Journal of Human Capital, 6(1), 35-55.

Christofides, L. N., Hoy, M., Li, Z., and Stengos, T. (2008). The Evolution of Aspirations for University Attendance. In R. Finnie, R. E. Mueller, A. Sweetman, and A. Usher (Eds.), Who goes? Who stays? What matters?: Accessing and persisting in postsecondary education in Canada (pp. 109-134). Montreal and Kingston: McGill-Queen's University Press.

Cohn, D., and Passel, J. S. (2011). Unauthorized Immigrant Population: National and State Trends, 2010. Washington, DC.

Colding, B., Husted, L., and Hummelgaard, H. (2009). Educational Progression of Secondgeneration Immigrants and Immigrant Children. Economics of Education Review, 28(4), 434-443.

Corak, M. (2012). Age at Immigration and the Education Outcomes of Children. In A. Masten, K. Liebkind, and D. J. Hernandez (Eds.), Realizing the Potential of Immigrant Youth (pp. 90-116). Cambridge: Cambridge University Press.

Corak, M., and Piraino, P. (2011). The Intergenerational Transmission of Employers. Journal of Labor Economics, 29(1), 37-68.

Currie, J. (2000). Do Children of Immigrants Make Differential Use of Public Health Insurance? In G. J. Borjas (Ed.), Issues in the Economics of Immigration (pp. 271-308). Chicago: University of Chicago Press. 
De Luca, G., Ponzo, M., and Andrés, A. R. (2013). Health Care Utilization by Immigrants in Italy. International Journal of Health Care Finance and Economics, 13(1), 1-31.

Dicks, G., and Sweetman, A. (1999). Education and Ethnicity in Canada: An Intergenerational Perspective. Journal of Human Resources, 34, 668-696.

Duncan, B., and Trejo, S. J. (2012). The Complexity of Immigrant Generations: Integration of Hispanics and Asians. IZA working paper.

Dustmann, C, Frattini, T., and Lanzara., G. (2012). Educational Achievement of Second Generation Immigrants: An International Comparison. Economic Policy, 69, 143-185.

Dustmann, C., and Theodoropoulos, N. (2010). Ethnic Minority Immigrants and Their Children in Britain. Oxford Economic Papers, 62(2), 209-233.

Dustmann, C., and Glitz, A. (2011). Migration and Education. In S. M. Eric A. Hanushek and L. Woessmann (Eds.), Handbook of The Economics of Education (Vol. 4, pp. 327-439).

Amsterdam: Elsevier.

Dustmann, C., Machin, S., and Schonberg, U. (2010). Ethnicity and Educational Achievement in Compulsory Schooling. Economic Journal, 120, F272-F297.

Ekberg, J., Hammarstedt, M., and Shukur, G. (2010). Immigrant-Native Earnings Differentials: SUR Estimation Applied on Three Generations. Annals of Regional Science, 45(3), 705720 .

Eurostat. (2011). Migrants in Europe: A Statistical Portrait of the First and Second Generation. Luxembourg: Publications Office of the European Union.

Fernández, R., and Fogli, A. (2009). Culture: An Empirical Investigation of Beliefs, Work, and Fertility. American Economic Journal Macroeconomics, 1(1), 146-177.

Finnie, R., and Mueller, R. E. (2010). They Came, They Saw, They Enrolled: Access to PostSecondary Education by the Children of Canadian Immigrants. In R Finnie, M. Frenette, R. E. Mueller, and A. Sweetman (Eds.), Pursuing Higher Education in Canada: Economic, Social, and Policy Dimensions (pp. 191-218). Montreal and Kingston: McGill-Queen's University Press.

Friedberg, R. (1993). The Labor Market Assimilation of Immigrants in the United States: The Role of Age at Arrival. Discussion Paper Brown University.

Friesen, J. and Krauth, B. (2011). Ethnic Enclaves in the Classroom. Labour Economics, 18, 656663.

Furtado, D. (2009). Cross-nativity Marriages and Human Capital of Children. Research in Labor Economics 29, 273-296. 
Furtado, D., and Trejo, S. J. (2013). Interethnic Marriages and their Economic Effects. In A. F. Constant and K. F. Zimmermann (Eds.), International Handbook on the Economics of Migration (pp. 276-292). Cheltenham: Edward Elgar Publishing.

Gang, I. N., and Zimmermann, K. F. (2000). Is Child Like Parent? Educational Attainment and Ethnic Origin. The Journal of Human Resources, 35(3), 1-21.

Geay, C., McNally, S., Telhaj, S. (2013). Non-native Speakers of English in the Classroom: What are the Effect on Pupuils Performance? Economic Journal, 123, F281-F307.

Gonzalez, A. (2003). The Education and Wages of Immigrant Children: The Impact of Age at Arrival. Economics of Education Review, 22, 203-212.

Gorinas, C. (2014). Ethnic Identity, Majority Norms, and the Native-Immigrant Employment Gap. Journal of Population Economics, 27, 225-250.

Gould, E.D., Lavy, V. and Paserman, D.M. (2009). Does Immigration Affect the Long-term Educational Outcomes of Natives? Quasi-experimental Evidence. Economic Journal, 119, 1243-1269.

Green, D. A., and Worswick, C. (2010). Entry Earnings of Immigrant Men in Canada: The Roles of Labour Market Entry Effects and Returns to Foreign Experience. In T. McDonald, E. Ruddick, A. Sweetman, and C. Worswick (Eds.), Canadian Immigration: Economic Evidence for a Dynamic Policy Environment. (pp. 77-110). Montreal and Kingston: McGillQueen's University Press.

Hammarstedt, M. (2009). Intergenerational Mobility and the Earnings Position of First-, Second-, and Third-Generation Immigrants. Kyklos, 62(2), 275-292.

Hammarstedt, M., and Palme, M. (2012). Human capital transmission and the earnings of secondgeneration immigrants in Sweden, IZA Journal of Migration, 1(4), 1-23.

Hanushek, E. A., and Woessmann, L. (2008). The Role of Cognitive Skills in Economic Development. Journal of Economic Literature, 46(3), 607-68.

Heath, A., and Kilpi-Jakonen, E. (2012). Immigrant Children's Age at Arrival and Assessment Results. Education Working Papers. OECD.

Hertz, T., Jayasundera, T., Piraino, P., Selcuk, S., Smith, N., and Verashchagina, A. (2007). The Inheritance of Educational Inequality: International Comparisons and Fifty-year Trends. B.E. Journal of Economic Analysis \& Policy, 7(2), 1-46.

Hoxby, C. M. (1998). Do Immigrants Crowd Disadvantaged American Natives Out of Higher Education? In D. S. Hamermesh and F. D. Bean (Eds.), Help or Hindrance? The economic implications of immigration for African-Americans (pp. 282-321). New York: Russell Sage Foundation. 
Hunt, J. (2012). The Impact of Immigration on the Educational Attainment of Natives, NBER Working Paper 18047.

Jackson, O. (2011). Does Immigration Crowd Natives Into or Out of Higher Education? Discussion Paper Northeastern University.

Jensen, P. and Rasmussen, A. (2011). The Effect of Immigrant Concentration in Schools on Native and Immigrant Children's Reading and Math Skills. Economics of Education Review, $30,1503-1515$.

Krause, A., Rinne, U., and Schueller, S. (2012). Kick it like Özil? Decomposing the NativeMigrant Education Gap. Discussion Paper. IZA.

Kuhn, P., and Sweetman, A. (2002). Aboriginals as Unwilling Immigrants: Contact, Assimilation and Labour Market Outcomes. Journal of Population Economics, 15(2), 331-355.

Lewis, E. G. (2011). Immigrant-Native Substitutability: The Role of Language Ability. NBER Working Paper 17609

Li, Q., and Sweetman, A. (2014). The Quality of Immigrant Source Country Educational Outcomes: Do they Matter in the Receiving Country? Labour Economics, forthcoming.

Liebig, T., and Widmaier, S. (2010). Overview: Children of Immigrants in the Labour Markets of OECD and EU Countries. In Equal Opportunities? The Labour Market Integration of the Children of Immigrants (pp. 15-54). Paris: OECD Publishing.

Lillard, D. R. (2013). Is Smoking Behavior Culturally Determined? Evidence From British Immigrants. Working Paper Series. NBER.

Lüdemann, E., and Schwerdt, G. (2013). Migration Background and Educational Tracking: Is There a Double Disadvantage for Second-Generation Immigrants? Journal of Population Economics, 26, 455-481.

Luttmer, E. F. P., and Singhal, M. (2011). Culture, Context, and the Taste for Redistribution. American Economic Journal: Economic Policy, 3, 157-179.

Manski, C. F. (1993). Identification of Endogenous Social Effects: The Reflection Problem. The Review of Economic Studies, 60, 531-542.

Messinis, G. (2009). Earnings and Languages in the Family: Second-Generation Australians. Economic Record, 85, S59-S73.

Meunier, M. (2011). Immigration and Student Achievement: Evidence from Switzerland. Economics of Education Review, 30(1), 16-38. 
Meunier, M., de Coulon, A., Marcenaro-Gutierrez, O., and Vignoles, A. (2013). A Longitudinal Analysis of UK Second-Generation Disadvantaged Immigrants. Education Economics, $21(2), 105-134$.

Moschion, J., and Tabasso, D. (2013). Trust of Second Generation Immigrants: Intergenerational Transmission or Cultural Assimilation? IZA Discussion Paper.

Nielsen, H. S., and Rangvid, B. S. (2012). The Impact of Parents' Years since Migration on Children's Academic Achievement. IZA Journal of Migration, 1, 1-23.

Nielsen, H. S., Rosholm, M., Smith, N., and Husted, L. (2003). The School-to-Work Transition of 2nd Generation Immigrants in Denmark. Journal of Population Economics, 16(4), 755786.

OECD. (2010). PISA 2009 Results: Learning Trends (Vol V), Paris: OECD.

OECD. (2011). Employment Outlook. Paris: OECD.

OECD. (2012). PISA - Untapped Skills: Realising the Potential of Immigrant Students. OECD Publishing.

Ohinata, A., and van Ours, J. C. (2012). Young Immigrant Children and their Educational Attainment. Economics Letters, 116, 288-290.

Ohinata, A., van Ours, J.C. (2013). How Immigrant Children Affect the Academic Achievement of Native Dutch Children. Economic Journal, 123, F308-F331.

Oreopoulos, P. (2011). Why Do Skilled Immigrants Struggle in the Labor Market? A Field Experiment with Thirteen Thousand Resumes. American Economic Journal: Economic Policy, 3(4), 148-171.

Pekkarinen, T., Uusitalo, R., and Kerr, S. (2009). School Tracking and Intergenerational Income Mobility: Evidence from the Finnish Comprehensive School Reform. Journal of Public Economics, 93, 965-973.

Ramakrishnan, S. K. (2004). Second-generation immigrants? The " 2.5 generation" in the United States. Social Science Quarterly, 85, 380-399.

Rooth, D.-O., and Ekberg, J. (2003). Unemployment and Earnings for Second Generation Immigrants in Sweden: Ethnic Background and Parent Composition. Journal of Population Economics, 16(4), 787-814.

Rumbaut, R. G. (2004). Ages, Life Stages, and Generational Cohorts: Decomposing the Immigrant First and Second Generations in the United States. International Migration Review, 38(3), 1160-1205. 
Sacerdote, B. (2011). Peer Effects in Education: How Might They Work, How Big Are They and How Much Do We Know Thus Far? In Handbook of the Economics of Education (Vol. 3, pp. 249-277).

Schaafsma, J., and Sweetman, A. (2001). Immigrant Earnings: Age at Immigration Matters. The Canadian Journal of Economics, 34(4), 1066-1099.

Schnepf, S. V. (2007). Immigrants' Educational Disadvantage: An Examination Across Ten Countries and Three Surveys. Journal of Population Economics, 20, 527-545.

Shertzer, A. (2013). Immigrant Group Size and Political Mobilization: Evidence from European Migration to the United States. NBER Working Paper 18827.

Skuterud, M. (2010). The Visible Minority Earnings Gap Across Generations of Canadians. Canadian Journal of Economics, 43(3), 862-881.

Smith, J. P. (2003). Assimilation across the Latino Generations. American Economic Review, Papers and Proceedings, 93(2), 315-25.

Solon, G. (1989). Biases in the Estimation of Intergenerational Earnings Correlations. Review of Economics and Statistics, 71, 172-174.

Solon, G. (1992). Intergenerational Income Mobility in the United States. American Economic Review, 82, 393-408.

Solon, G. (1999). Intergenerational Mobility in the Labor Market. In O. C. Ashenfelter and D. Card (Eds.), Handbook of Labor Economics, Vol 3A (pp. 1761-1800). Amsterdam: Elsevier B.V.

Solon, G. (2013). Theoretical Models of Inequality Transmission across Multiple Generations. NBER Working Paper 18790.

Statistics Canada. (2008). Canada’s Ethnocultural Mosaic, 2006 Census (pp. 1-36).

Sweetman, A. (2010). Immigrant Children in Elementary School: An International Perspective. In T. McDonald, E. Ruddick, A. Sweetman, and C. Worswick (Eds.), Canadian Immigration: Economic Evidence for a Dynamic Policy Environment (pp. 257-81). McGillQueen's University Press.

Trejo, S. J. (2003). Intergenerational Progress of Mexican-Origin Workers in the U.S. Labor Market. Journal of Human Resources, 38(3), 467-489.

Tu, J. (2010). Explaining the Labour Market Outcomes of First, Second and Third-generation Immigrants in Canada. Discussion Paper. IZA. 
Van Ours, J. C., and Veenman, J. (2003). The Educational Attainment of Second-generation Immigrants in the Netherlands. Journal of Population Economics, 16, 739-753.

Van Ours, J. C., and Veenman, J. (2004). From Parent to Child: Early Labor Market Experiences of Second-generation Immigrants in the Netherlands. De Economist, 152, 473-490.

Van Ours, J. C., and Veenman, J. (2006). Age at Immigration and Educational Attainment of Young Immigrants. Economics Letters, 90(3), 310-316.

Van Ours, J. C., and Veenman, J. (2010). How Interethnic Marriages Affect the Educational Attainment of Children: Evidence from a Natural Experiment. Labour Economics, 17, 111117.

Wilson, D., Burgess, S., and Briggs, A. (2011). The Dynamics of School Attainment of England's Ethnic Minorities. Journal of Population Economics, 24, 681-700.

Woolf, J. (2010). The Economic and Social Outcomes of Children of Migrants in New Zealand. Statistics New Zealand.

Worswick, C. (2009). Adaptation and Inequality: Children of Immigrants in Canadian Schools. Canadian Journal of Economics, 37(1), 53-77.

Zimmerman, D. (1992). Regression Toward Mediocrity in Economic Stature. American Economic Review, 82, 409-429. 
Table 1: Immigrant Population by Generation (circa 2008)

\begin{tabular}{|c|c|c|c|}
\hline \multicolumn{4}{|c|}{ Adult Immigrants } \\
\hline First & & nd Generati & \\
\hline & $\begin{array}{l}1 \text { Parent } \\
\text { Immigrant }\end{array}$ & $\begin{array}{l}2 \text { Parents } \\
\text { Immigrant }\end{array}$ & Total \\
\hline
\end{tabular}

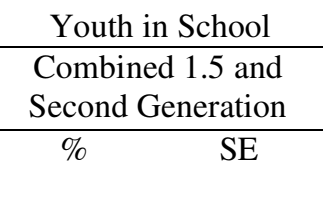

\begin{tabular}{|c|c|c|c|c|c|c|}
\hline Albania & - & -- & -- & -- & 0.6 & $(0.2)$ \\
\hline Argentina & - & -- & -- & -- & 3.6 & $(0.5)$ \\
\hline Australia & 24 & 11.3 & 8.7 & 20.0 & 23.2 & (1.1) \\
\hline Austria & 18.4 & 5.0 & 1.9 & 6.9 & -- & -- \\
\hline Belgium & 14.7 & 4.1 & 4.0 & 8.1 & 14.8 & $(1.1)$ \\
\hline Brazil & - & -- & -- & -- & 0.8 & $(0.1)$ \\
\hline Bulgaria & - & -- & -- & -- & 0.5 & $(0.1)$ \\
\hline Canada & 22.6 & 7.5 & 6.8 & 14.3 & 24.4 & (1.3) \\
\hline Chile & - & -- & -- & -- & 0.5 & $(0.1)$ \\
\hline Cyprus & 23.3 & 1.3 & - & - & -- & -- \\
\hline Czech Republic & 3.0 & 3.3 & 0.9 & 4.2 & 2.3 & $(0.2)$ \\
\hline Denmark & 8.6 & - & - & - & 8.6 & $(0.4)$ \\
\hline Estonia & 13.6 & 8.9 & 13.1 & 22.0 & -- & -- \\
\hline Finland & - & -- & -- & -- & 2.6 & $(0.3)$ \\
\hline France & 13.1 & 7.7 & 5.8 & 13.5 & 13.1 & (1.4) \\
\hline Germany & 17.6 & 1.4 & 2.9 & 4.3 & 17.6 & $(1.0)$ \\
\hline Greece & 10.4 & 0.7 & 0.6 & 1.3 & 9.0 & $(0.8)$ \\
\hline Hong Kong & - & -- & -- & -- & 39.4 & $(1.5)$ \\
\hline Hungary & 2.2 & 0.6 & 0.3 & 0.9 & 2.1 & $(0.3)$ \\
\hline Iceland & - & -- & -- & -- & 2.4 & $(0.2)$ \\
\hline Indonesia & - & -- & -- & -- & 0.3 & $(0.1)$ \\
\hline Ireland & 22.4 & 2.2 & 0.7 & 2.9 & 8.3 & $(0.6)$ \\
\hline Israel & - & -- & -- & -- & 19.7 & $(1.1)$ \\
\hline Italy & 10.6 & 0.9 & 0.1 & 1.0 & 5.5 & $(0.3)$ \\
\hline Japan & - & -- & -- & -- & 0.3 & $(0.1)$ \\
\hline Korea & - & -- & -- & -- & 0.0 & $(0.0)$ \\
\hline Latvia & - & -- & -- & -- & 4.5 & $(0.5)$ \\
\hline Lithuania & 54.2 & 2.5 & - & - & -- & -- \\
\hline Luxembourg & 48 & 7.3 & 6.6 & 13.9 & 40.2 & $(0.7)$ \\
\hline Mexico & - & -- & -- & -- & 1.9 & $(0.2)$ \\
\hline Netherlands & 15 & 5.8 & 2.7 & 8.5 & 12.1 & (1.4) \\
\hline New Zealand & 23 & 15.1 & 10.4 & 25.5 & 24.7 & $(1.0)$ \\
\hline Norway & - & -- & -- & -- & 6.8 & $(0.6)$ \\
\hline Peru & - & -- & -- & -- & 0.4 & $(0.1)$ \\
\hline Poland & 0.3 & 2.1 & 0.8 & 2.9 & 0.0 & $(0.0)$ \\
\hline Portugal & 10.5 & 0.8 & 0.4 & 1.2 & 5.5 & $(0.5)$ \\
\hline Russian Federation & - & - & - & - & 12.1 & $(0.7)$ \\
\hline Romania & 0.2 & - & - & - & 0.3 & $(0.1)$ \\
\hline Slovak Republic & 0.9 & 1.6 & 0.4 & 2.0 & -- & -- \\
\hline Slovenia & 9.0 & 5.1 & 2.6 & 7.7 & -- & -- \\
\hline Spain & 19.1 & 0.9 & 0.2 & 1.1 & 9.5 & $(0.5)$ \\
\hline Sweden & 16.2 & 6.7 & 2.9 & 9.6 & 11.7 & $(1.2)$ \\
\hline
\end{tabular}




$\begin{array}{lllllll}\text { Switzerland } & 31.1 & 9.6 & 5.7 & 15.3 & 23.5 & (0.9) \\ \text { United Kingdom } & 15.6 & 5.0 & 3.8 & 8.8 & 10.6 & (1.0) \\ \text { United States } & 14.6 & 3.7 & 2.3 & 6.0 & 19.5 & (1.3)\end{array}$

Note: In the case of Germany the country of birth of the parents is approximated by the nationality of the parents. Ages represented: Europe, 25-54; Canada and United States, 25-64; Australia, all ages; New Zealand, 15 and over.

Source: Eurostat (2011); Aydemir and Sweetman (2008) using American CPS data from 1998 to 2004, and 2006 Canadian census data; Woolf (2010) for New Zealand using GSS and census data; Australian Bureau of Statistics (2009), but imputing the one and two immigrant parent breakdown from 1996 census in Birrell et al. (2002). 
Table 2: Educational attainment by generation for selected countries

Percentage with low education

\begin{tabular}{llll}
\hline Native & $\begin{array}{l}\text { First } \\
\text { Gen. }\end{array}$ & Second Generation \\
\cline { 3 - 3 } & & & \\
\cline { 3 - 4 } & & 1 parent & 2 parents \\
& & immigrant & immigrant
\end{tabular}

Percentage with high education

\begin{tabular}{llll}
\hline Native & $\begin{array}{l}\text { First } \\
\text { Gen. }\end{array}$ & Second Generation \\
\cline { 3 - 3 } & & & \\
\cline { 3 - 3 } & & 1 parent & 2 parents \\
& & immigrant & immigrant
\end{tabular}

\begin{tabular}{|c|c|c|c|c|c|c|c|c|}
\hline Austria & 12 & 27 & 13 & 24 & 19 & 19 & 24 & - \\
\hline Belgium & 23 & 36 & 32 & 33 & 36 & 32 & 30 & 20 \\
\hline Canada & 24 & 23 & 19 & 14 & 37 & 45 & 44 & 50 \\
\hline Cyprus & 20 & 23 & - & - & 39 & 37 & 46 & - \\
\hline Czech Republic & 7 & 18 & 9 & 29 & 16 & 21 & 13 & - \\
\hline Denmark & 21 & 29 & - & - & 36 & 34 & - & - \\
\hline Estonia & 11 & - & 12 & 8 & 27 & 21 & 28 & 14 \\
\hline France & 23 & 43 & 24 & 26 & 31 & 26 & 35 & 29 \\
\hline Germany & 8 & 34 & - & 19 & 27 & 21 & 28 & 14 \\
\hline Greece & 32 & 47 & - & 40 & 26 & 15 & 30 & - \\
\hline Hungary & 18 & 14 & - & - & 20 & 31 & 26 & - \\
\hline Ireland & 28 & 16 & 19 & - & 34 & 47 & 47 & 53 \\
\hline Italy & 42 & 44 & 27 & - & 16 & 12 & 25 & - \\
\hline Lithuania & 7 & - & - & - & 32 & - & - & - \\
\hline Luxembourg & 28 & 31 & 27 & 23 & 26 & 37 & 17 & 17 \\
\hline Netherlands & 22 & 39 & 24 & 29 & 35 & 27 & 35 & 29 \\
\hline New Zealand & 20 & - & 22 & 17 & 29 & - & 29 & 34 \\
\hline Poland & 10 & - & 11 & - & 22 & 51 & 18 & 16 \\
\hline Portugal & 70 & 50 & 53 & 59 & 15 & 22 & 28 & - \\
\hline Slovak Republic & 8 & - & - & - & 15 & 26 & 18 & - \\
\hline Slovenia & 14 & 34 & - & - & 25 & - & 27 & - \\
\hline Spain & 43 & 40 & 33 & 55 & 35 & 24 & 40 & 21 \\
\hline Sweden & 13 & 29 & 14 & 15 & 34 & 35 & 32 & 28 \\
\hline Switzerland & 5 & 27 & 6 & 7 & 36 & 35 & 39 & 31 \\
\hline United Kingdom & 25 & 20 & 20 & 22 & 33 & 34 & 43 & 45 \\
\hline United States & 10 & 31 & 5 & 11 & 40 & 34 & 45 & 45 \\
\hline
\end{tabular}

Note: For the European countries, mixed background is defined as "persons who are native born and who have one foreign-born parent and one native-born parent. A foreign background is defined as persons who are native born with both parents being foreign-born." (Eurostat. 2011. 121). Canada and U.S. samples aged 25-65; with the data from Aydemir and Sweetman (2008); immigrants include the 1.0 and 1.5 generations; while mixed and foreign include the second generation one and two foreign born parents respectively. New Zealand's data are from Woolf (2010) using a sample from ages 15 to 64; the second generation includes both the 1.5 and second generation. Low education is defined as up to level International Standard Classification of Education (ISCED) level 3c short. High education is equivalent to tertiary education defined as ISCED levels 5-6. In case of Germany the country of birth of the parents is approximated by the nationality of the parents. Source: Eurostat (2011). 
Table 3: Immigrants in National School Systems from the 2009 portion of the OECD's PISA Program

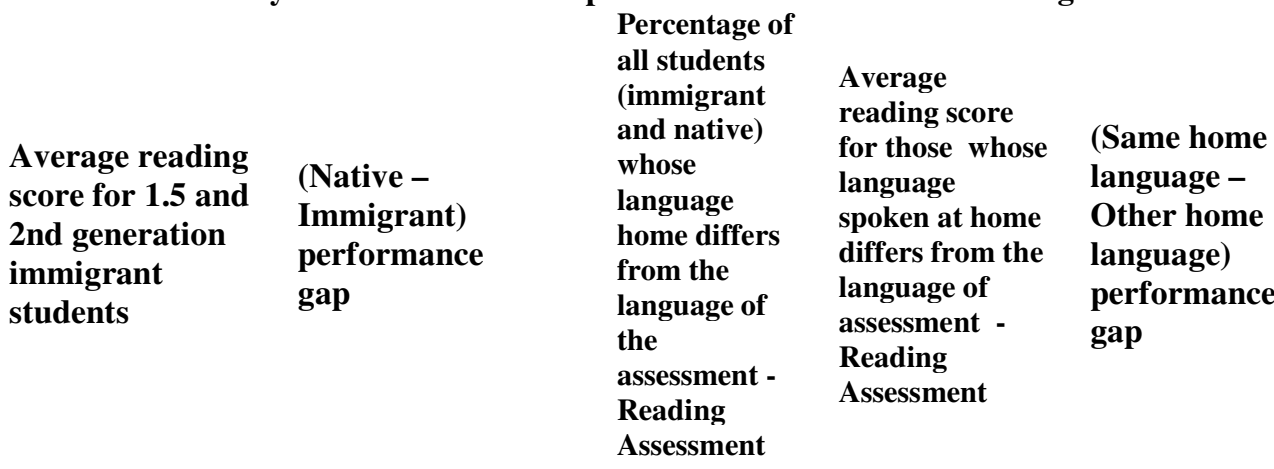

\begin{tabular}{|c|c|c|c|c|c|c|c|c|c|c|}
\hline & $\begin{array}{l}\text { Mean } \\
\text { score }\end{array}$ & S.E. & $\begin{array}{c}\text { Score } \\
\text { dif. }\end{array}$ & S.E. & $\%$ & S.E. & $\begin{array}{l}\text { Mean } \\
\text { score }\end{array}$ & S.E. & $\begin{array}{l}\text { Score } \\
\text { dif. }\end{array}$ & S.E. \\
\hline Australia & 524 & $(5.8)$ & -10 & $(5.8)$ & 9.2 & $(0.7)$ & 509 & $(8.9)$ & 10 & $(8.3)$ \\
\hline Austria & -- & -- & -- & -- & -- & -- & -- & -- & -- & -- \\
\hline Belgium & 451 & $(6.4)$ & 68 & $(6.3)$ & 21.6 & $(1.1)$ & 480 & $(5.6)$ & 38 & (5.6) \\
\hline Canada & 521 & $(3.4)$ & 7 & $(3.6)$ & 14.2 & $(0.8)$ & 512 & $(3.9)$ & 18 & (4.1) \\
\hline Chile & -- & -- & -- & -- & 0.5 & $(0.1)$ & $\mathrm{c}$ & $\mathrm{c}$ & $\mathrm{c}$ & $\mathrm{c}$ \\
\hline Czech Republic & 457 & (13.7) & 22 & (13.2) & 1.3 & $(0.2)$ & 477 & $(16.5)$ & 4 & (16.1) \\
\hline Denmark & 438 & $(3.8)$ & 63 & (3.9) & 4.5 & $(0.3)$ & 434 & $(5.3)$ & 67 & $(5.2)$ \\
\hline Finland & 468 & (12.8) & 70 & (12.7) & 3.7 & $(0.3)$ & 477 & $(7.8)$ & 61 & (7.5) \\
\hline France & 444 & $(8.5)$ & 60 & $(9.2)$ & 7.0 & $(0.6)$ & 433 & $(9.2)$ & 72 & (9.7) \\
\hline Germany & 455 & $(4.7)$ & 56 & $(4.8)$ & 10.5 & $(0.8)$ & 452 & $(6.4)$ & 58 & $(6.4)$ \\
\hline Greece & 432 & (11.5) & 57 & (11.1) & 4.8 & $(0.6)$ & 408 & (14.8) & 79 & (14.6) \\
\hline Hungary & 507 & $(8.3)$ & -12 & $(8.4)$ & 1.0 & $(0.3)$ & 403 & $(35.0)$ & 93 & $(35.0)$ \\
\hline Iceland & 423 & $(11.7)$ & 81 & (11.7) & 3.1 & $(0.3)$ & 435 & $(10.7)$ & 69 & (10.8) \\
\hline Ireland & 473 & $(7.1)$ & 29 & $(7.3)$ & 5.8 & $(0.9)$ & 467 & (13.9) & 34 & (13.7) \\
\hline Israel & 478 & $(6.4)$ & 2 & $(6.1)$ & 11.8 & $(1.1)$ & 470 & (11.5) & 11 & (11.9) \\
\hline Italy & 418 & $(4.2)$ & 72 & $(4.4)$ & 14.3 & $(0.4)$ & 441 & $(3.0)$ & 62 & (3.2) \\
\hline Japan & $\mathrm{c}$ & $\mathrm{c}$ & $\mathrm{c}$ & $\mathrm{c}$ & 0.2 & $(0.1)$ & $\mathrm{c}$ & $\mathrm{c}$ & $\mathrm{c}$ & $\mathrm{c}$ \\
\hline Korea & $\mathrm{c}$ & $\mathrm{c}$ & $\mathrm{c}$ & $\mathrm{c}$ & 0.1 & $(0.0)$ & $\mathrm{c}$ & $\mathrm{c}$ & $\mathrm{c}$ & $\mathrm{c}$ \\
\hline Luxembourg & 442 & $(2.1)$ & 52 & $(3.0)$ & 88.9 & $(0.4)$ & 479 & $(1.5)$ & 40 & (4.9) \\
\hline Mexico & 331 & $(7.9)$ & 99 & $(7.5)$ & 2.8 & $(0.3)$ & 334 & $(8.0)$ & 95 & $(8.0)$ \\
\hline Netherlands & 470 & $(7.8)$ & 46 & $(8.0)$ & 6.4 & $(0.8)$ & 474 & (11.4) & 39 & $(10.8)$ \\
\hline New Zealand & 513 & $(4.7)$ & 13 & $(5.3)$ & 14.5 & $(0.7)$ & 474 & $(5.5)$ & 56 & $(5.7)$ \\
\hline Norway & 456 & $(5.9)$ & 52 & $(5.7)$ & 7.3 & $(0.5)$ & 451 & $(5.6)$ & 58 & $(5.3)$ \\
\hline Poland & $\mathrm{c}$ & $\mathrm{c}$ & $\mathrm{c}$ & $\mathrm{c}$ & 0.6 & $(0.1)$ & $\mathrm{c}$ & $\mathrm{c}$ & $\mathrm{c}$ & $\mathrm{c}$ \\
\hline Portugal & 466 & $(6.9)$ & 26 & $(7.0)$ & 1.6 & $(0.2)$ & 460 & $(9.4)$ & 31 & $(9.3)$ \\
\hline Spain & 430 & $(4.0)$ & 58 & (3.9) & 18.1 & $(1.0)$ & 471 & $(3.8)$ & 13 & (3.6) \\
\hline Sweden & 442 & $(6.9)$ & 66 & $(7.2)$ & 8.1 & $(0.9)$ & 435 & $(7.7)$ & 72 & (7.7) \\
\hline Switzerland & 465 & $(4.1)$ & 48 & $(3.5)$ & 15.5 & $(0.7)$ & 460 & $(3.6)$ & 54 & (3.2) \\
\hline United Kingdom & 476 & $(7.5)$ & 23 & $(7.6)$ & 6.2 & $(0.6)$ & 453 & $(8.3)$ & 46 & $(8.4)$ \\
\hline United States & 484 & $(5.8)$ & 22 & $(5.5)$ & 13.1 & $(1.0)$ & 471 & $(5.8)$ & 34 & $(5.9)$ \\
\hline OECD average-26 & 458 & $(1.6)$ & 43 & $(1.6)$ & 7.5 & $(0.1)$ & 453 & $(2.4)$ & 50 & (2.4) \\
\hline
\end{tabular}




\section{Partners}

$\begin{array}{lrrrrrrrrrr}\text { Albania } & \mathrm{c} & \mathrm{c} & \mathrm{c} & \mathrm{c} & 1.0 & (0.2) & 358 & (18.9) & 28 & (18.9) \\ \text { Argentina } & 362 & (15.2) & \mathbf{4 0} & (15.6) & 1.4 & (0.2) & 320 & (18.2) & \mathbf{8 2} & (17.8) \\ \text { Brazil } & 317 & (13.5) & \mathbf{9 9} & (13.8) & 0.7 & (0.1) & 354 & (11.2) & \mathbf{5 9} & (11.3) \\ \text { Bulgaria } & \mathrm{c} & \mathrm{c} & \mathrm{c} & \mathrm{c} & 10.9 & (1.7) & 342 & (9.7) & \mathbf{1 0 2} & (10.1) \\ \text { Hong Kong-China } & 531 & (3.4) & 4 & (4.3) & 7.2 & (1.1) & 480 & (8.8) & \mathbf{5 8} & (9.0) \\ \text { Indonesia } & \mathrm{c} & \mathrm{c} & \mathrm{c} & \mathrm{c} & 64.4 & (2.1) & 399 & (3.6) & 9 & (6.4) \\ \text { Latvia } & 474 & (9.0) & 11 & (8.4) & 9.4 & (1.3) & 469 & (9.4) & 18 & (9.7) \\ \text { Liechtenstein } & 479 & (7.4) & \mathbf{3 1} & (10.3) & 15.0 & (2.2) & 451 & (11.7) & \mathbf{6 0} & (13.4) \\ \text { Peru } & \mathrm{c} & \mathrm{c} & \mathrm{c} & \mathrm{c} & 5.3 & (0.9) & 270 & (7.0) & \mathbf{1 0 7} & (7.8) \\ \text { Romania } & \mathrm{c} & \mathrm{c} & \mathrm{c} & \mathrm{c} & 3.2 & (0.6) & 359 & (12.8) & \mathbf{6 8} & (12.7) \\ \text { Russian Federation } & 439 & (7.0) & \mathbf{2 5} & (6.8) & 9.6 & (1.5) & 410 & (8.3) & \mathbf{5 5} & (8.7) \\ \text { Thailand } & \mathrm{c} & \mathrm{c} & \mathrm{c} & \mathrm{c} & 48.6 & (1.6) & 413 & (3.5) & \mathbf{1 8} & (4.3)\end{array}$

Note: The OECD average reading score is 493, and the standard deviation is about 100. Cells with "c" have too few observations to provide reliable estimates, and data are not available for those with "--“.

Source: (OECD, 2010). 
Table 4: Unemployment rates and employment rates; children of natives and native born children of immigrants. around 2007

\begin{tabular}{|c|c|c|c|c|c|c|c|c|}
\hline & \multicolumn{4}{|c|}{ Unemployment rates } & \multicolumn{4}{|c|}{ Employment rates } \\
\hline & \multicolumn{2}{|c|}{ Men } & \multicolumn{2}{|c|}{ Women } & \multicolumn{2}{|c|}{ Men } & \multicolumn{2}{|c|}{ Women } \\
\hline & $3+$ & $2 \mathrm{G}$ & $3+$ & $2 \mathrm{G}$ & $3+$ & $2 \mathrm{G}$ & $3+$ & $2 \mathrm{G}$ \\
\hline Australia & 6 & 8 & 5 & 5 & 88 & 86 & 76 & 79 \\
\hline Austria & 6 & - & 5 & - & 90 & 81 & 79 & 66 \\
\hline Belgium & 11 & 28 & 12 & 27 & 81 & 61 & 77 & 54 \\
\hline Canada & 8 & 7 & 7 & 8 & 85 & 85 & 78 & 83 \\
\hline Denmark & 2 & 6 & 3 & 8 & 85 & 75 & 81 & 72 \\
\hline France & 12 & 21 & 13 & 21 & 83 & 72 & 75 & 62 \\
\hline Germany & 18 & 27 & 13 & 20 & 79 & 69 & 73 & 62 \\
\hline Luxembourg & 6 & 11 & 11 & 22 & 92 & 86 & 83 & 75 \\
\hline Netherlands & 5 & - & 4 & - & 91 & 70 & 87 & 67 \\
\hline New Zealand & 5 & - & 7 & 10 & 92 & 89 & 78 & 80 \\
\hline Norway & 3 & 4 & 3 & 3 & 86 & 77 & 82 & 72 \\
\hline Spain & 13 & - & 13 & - & 80 & 76 & 75 & 57 \\
\hline Sweden & - & - & - & - & 85 & 73 & 82 & 71 \\
\hline Switzerland & 4 & - & 4 & - & 90 & 89 & 90 & 91 \\
\hline UK & 9 & 15 & 7 & 10 & 82 & 79 & 75 & 66 \\
\hline United States & 9 & 9 & 7 & - & 81 & 80 & 73 & 74 \\
\hline
\end{tabular}

Employment rates by education level

\begin{tabular}{|c|c|c|c|c|c|c|c|c|c|c|c|c|}
\hline & \multicolumn{6}{|l|}{ Men } & \multicolumn{6}{|c|}{ Women } \\
\hline & Low & & Medium & & High & & Low & & Medium & & High & \\
\hline & $3+$ & $2 \mathrm{G}$ & $3+$ & $2 \mathrm{G}$ & $3+$ & $2 \mathrm{G}$ & $3+$ & $2 \mathrm{G}$ & $3+$ & $2 \mathrm{G}$ & $3+$ & $2 \mathrm{G}$ \\
\hline Australia & 71 & 65 & 91 & 88 & 96 & 98 & 43 & 42 & 77 & 77 & 92 & 92 \\
\hline Austria & 87 & 71 & 92 & 90 & 96 & - & 56 & - & 80 & 74 & 88 & - \\
\hline Belgium & 68 & 47 & 82 & 69 & 88 & 79 & 49 & 32 & 71 & 57 & 89 & 82 \\
\hline Canada & 70 & 67 & 86 & 84 & 92 & 90 & 50 & 56 & 76 & 75 & 88 & 88 \\
\hline Denmark & 76 & 69 & 88 & 79 & 88 & 86 & 63 & 61 & 85 & 76 & 89 & 84 \\
\hline France & 68 & 55 & 86 & 78 & 88 & 85 & 46 & 43 & 73 & 60 & 87 & 80 \\
\hline Germany & 58 & 54 & 82 & 76 & 90 & 81 & 44 & 43 & 77 & 73 & 86 & 64 \\
\hline Luxembourg & 90 & 85 & 92 & - & 96 & - & 70 & 67 & 87 & - & 92 & - \\
\hline Netherlands & 81 & 53 & 94 & 80 & 96 & 93 & 66 & 48 & 90 & 75 & 94 & - \\
\hline New Zealand & 88 & 85 & 95 & 90 & 97 & 94 & 65 & 65 & 83 & 80 & 94 & 93 \\
\hline Norway & 75 & 72 & 91 & 86 & 92 & 86 & 67 & 62 & 86 & 80 & 92 & 83 \\
\hline Spain & 76 & 73 & 83 & 92 & 88 & - & 62 & 60 & 78 & - & 84 & 85 \\
\hline Sweden & 63 & 53 & 88 & 79 & 92 & 87 & 53 & 45 & 83 & 75 & 92 & 87 \\
\hline Switzerland & 69 & - & 90 & 91 & 94 & 96 & 65 & - & 90 & 93 & 94 & 92 \\
\hline UK & 71 & 61 & 89 & 80 & 92 & 90 & 44 & 28 & 77 & 66 & 92 & 86 \\
\hline United States & 60 & 57 & 80 & 80 & 91 & 89 & 43 & - & 68 & 70 & 87 & 86 \\
\hline
\end{tabular}


Table 5: Median wages of foreign-born relative to native-born by educational attainment. 2005/06

\begin{tabular}{lllll} 
& Overall & $\begin{array}{l}\text { Low } \\
\text { education }\end{array}$ & $\begin{array}{l}\text { Median } \\
\text { education }\end{array}$ & $\begin{array}{l}\text { High } \\
\text { education }\end{array}$ \\
\hline Australia & 1.07 & 1.11 & 1.02 & 0.98 \\
Canada & 0.95 & 1.07 & 0.94 & 0.89 \\
France & 0.90 & 0.94 & 0.96 & 0.90 \\
Germany & 0.93 & 1.14 & 0.93 & 0.91 \\
Netherlands & 0.85 & 1.11 & 1.02 & 0.98 \\
Portugal & 0.94 & 1.00 & 0.76 & 0.80 \\
Sweden & 0.93 & 0.91 & 0.94 & 0.92 \\
Switzerland & 0.89 & 1.05 & 0.93 & 0.96 \\
United States & 0.79 & 1.07 & 0.83 & 0.93 \\
\hline
\end{tabular}

Note: Median hourly wages of the foreign-born relative to median hourly wages of native-born in the same group. Age 15-64 years. Low education = up to lower secondary education. Medium education = completed upper secondary education. High education $=$ tertiary education.

Source: Dustmann and Glitz (2011) on the basis of the International Migration Outlook 2008 